\title{
OUT OF THE ROUGH: HOW CAN MUNICIPALITIES BETTER UTILIZE THEIR GOLF COURSE LANDS?
}

\author{
By
}

Darcy James Watt

Bachelor of Arts Honours, Laurentian University, 2017

\author{
A Major Research Paper \\ presented to Ryerson University
}

in partial fulfillment of the requirements for the degree of

Master of Planning

In

Urban Development

Toronto, Ontario, Canada, 2019

(C) Darcy James Watt 2019 


\section{Author's Declaration for Electronic Submission of a MRP}

I hereby declare that I am the sole author of this MRP. This is a true copy of the MRP, including any required final revisions.

I authorize Ryerson University to lend this MRP to other institutions or individuals for the purpose of scholarly research

I further authorize Ryerson University to reproduce this MRP by photocopying or by other means, in total or in part, at the request of other institutions or individuals for the purpose of scholarly research.

I understand that my MRP may be made electronically available to the public. 


\title{
OUT OF THE ROUGH: HOW CAN MUNICIPALITIES BETTER UTILIZE THEIR GOLF COURSE LANDS?
}

\author{
(C) Darcy James Watt, 2019 \\ Master of Planning \\ In \\ Urban Development \\ Ryerson University
}

\begin{abstract}
Golf has declined in recent years as younger generations fail to take up the sport leaving many municipally-owned golf courses in financial trouble. As cities face numerous growing challenges such as housing, public transit and the lack of public greenspaces, closing municipal golf courses has been touted as a possible solution. While municipal golf courses are open to the public, barriers to entry such as a dress code and green fees have left them inaccessible to many residents making them not truly public spaces. Municipal golf courses however do have benefits such as providing an affordable golfing experience in an urban setting. This research paper will look at how municipalities can better utilize their golf course lands with a focus on two City of Toronto municipal golf courses: Scarlett Woods Golf Course and Dentonia Park Golf Course. This paper highlights the different options cites could employ to adapt their golf facilities.
\end{abstract}

Key Words: golf, golf courses, parks and recreation, Toronto, redevelopment, adaptation, parks and physical activity, Scarlett Woods, Dentonia Park, 


\section{Acknowledgements}

I would like to thank my supervisor, Dr. Mitchell Kosny for his guidance and support throughout the writing of this paper. I would also like to thank Bruce McCall-Richmond for his assistance as my second reader. His insight and feedback were extremely valuable to this paper.

I would also like to thank all my friends and family for their support and in particular my parents David and Gwen and my sister Vanessa. Your unconditional love and support has allowed me to chase my goals and dreams and I truly love the three of you more than you could ever know. 


\section{Contents}

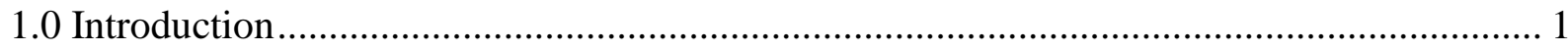

2.0 Overview of the Golf Industry and Golf in Toronto ........................................................ 5

2.1 The History and Current State of Golf in the Greater Toronto Area ................................. 5

2.2 Current state of City of Toronto Golf Operations.......................................................... 8

2.3 Overview of Golf Course Redevelopment in the Greater Toronto Area ........................ 10

3.0 Examination of Golf Course Adaptation and Redevelopment Options .............................. 12

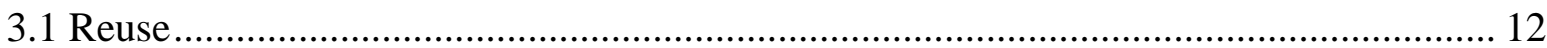

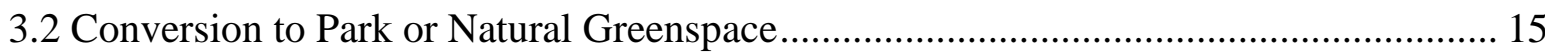

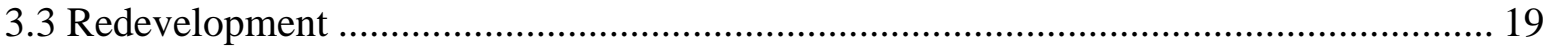

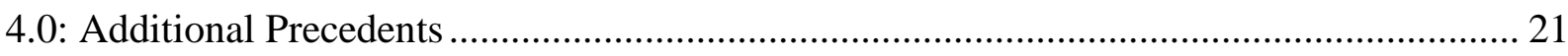

5.0 Best Practices ……………………………………............................................. 29

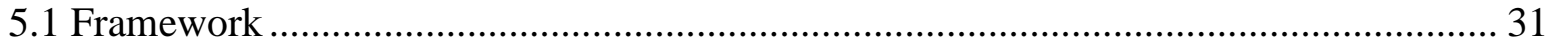

6.0 Case Studies of City of Toronto Municipal Golf Courses ................................................. 34

6.1 Scarlett Woods Golf Course Context........................................................................... 34

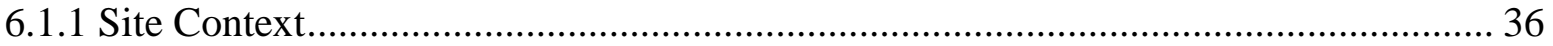

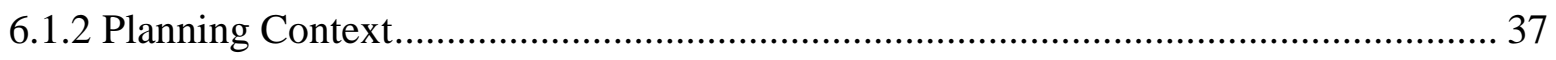

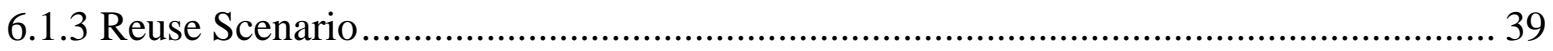

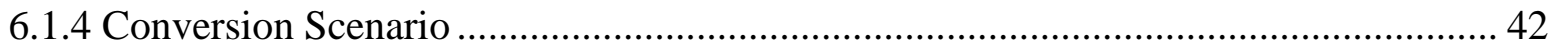

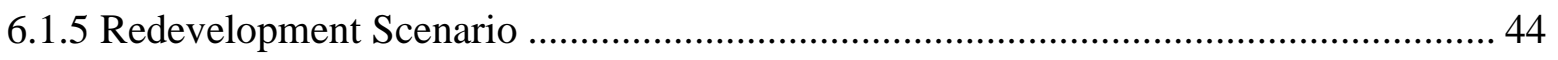

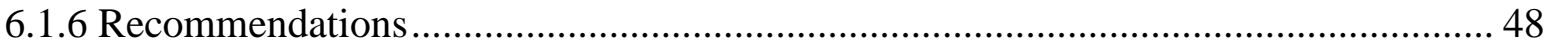

6.2 Dentonia Park Golf Course Context .............................................................................. 51

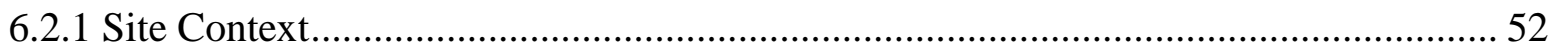

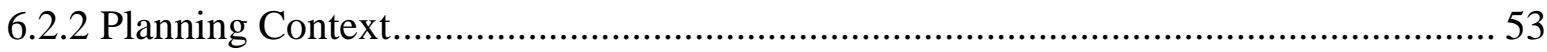

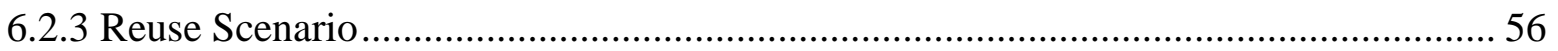

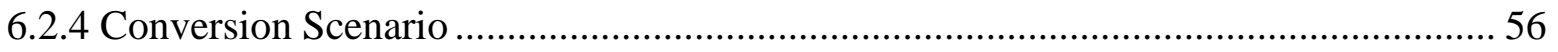

6.2.5 Redevelopment Scenario ........................................................................................ 59

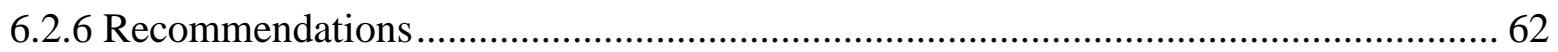

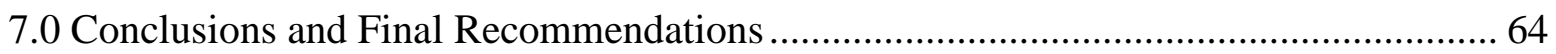

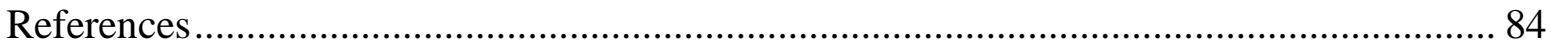




\section{Tables}

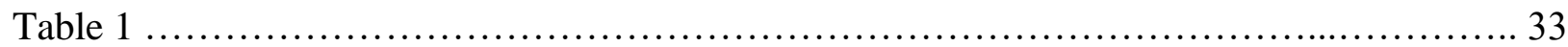




\section{Figures}

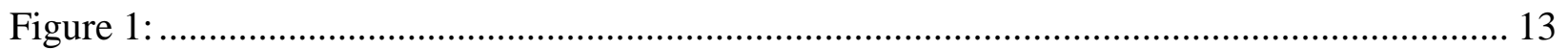

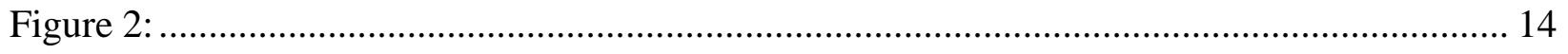

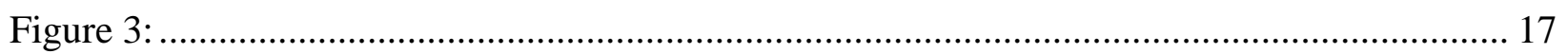

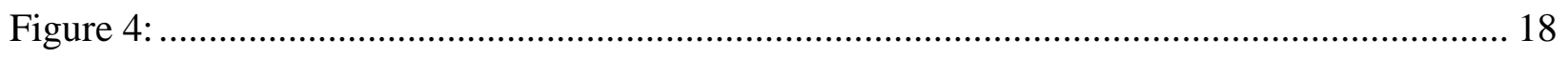

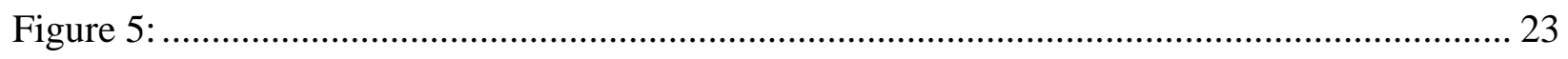

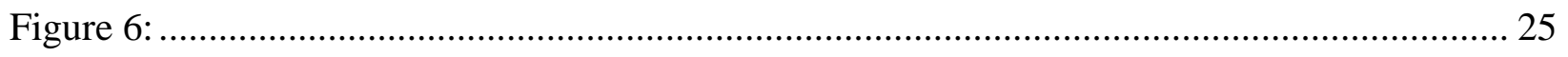

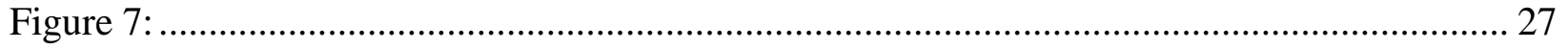

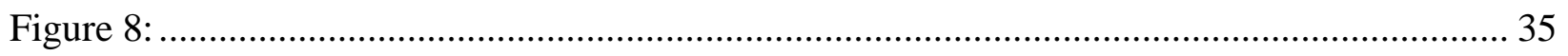

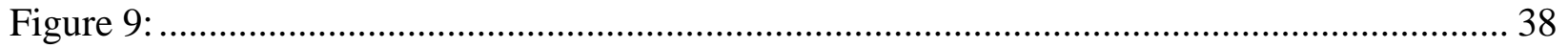

Figure 10:

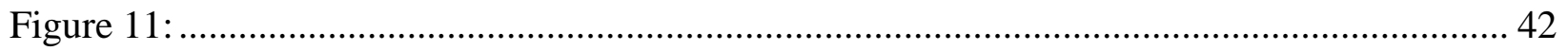

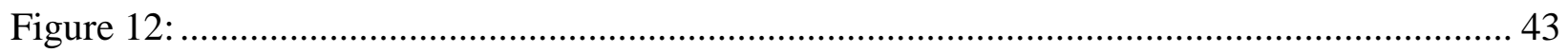

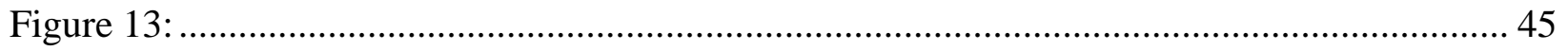

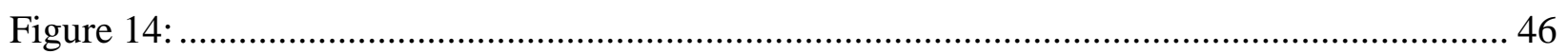

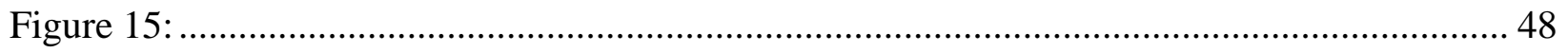

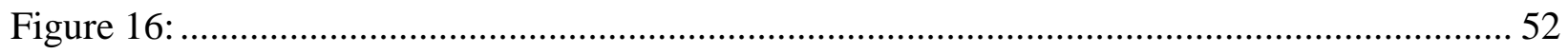

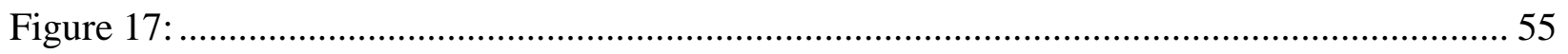

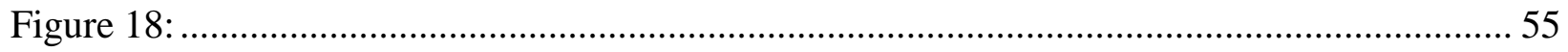

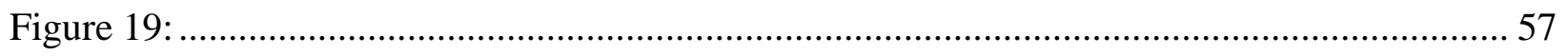

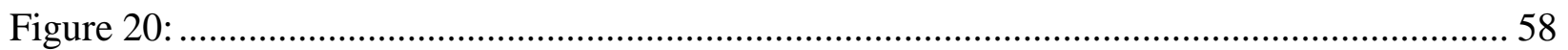

Figure 21:

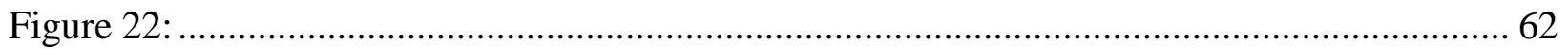




\section{Appendices}

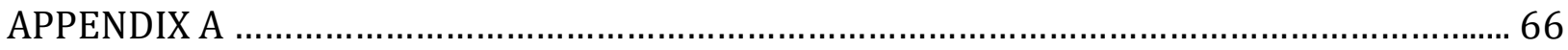

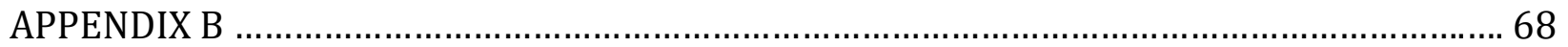

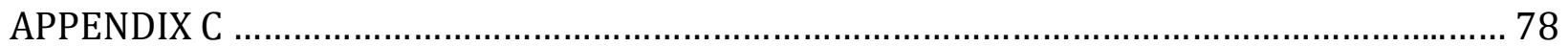




\subsection{Introduction}

The City of Toronto currently owns and operates a vast array of parks, playgrounds and sporting facilities across the city. Included in these assets are five publicly owned golf courses; Dentonia Park, Don Valley, Humber Valley, Scarlett Woods and Tam O’Shanter.

These courses offer an affordable and unique experience for golfers of all skill levels and have become fixtures in the Toronto golf community over the past few decades. The courses however have fallen on hard times in recent years each seeing a steep decline in rounds played per year and in revenue (Artuso, 2018). These trends can be attributed to the overall decline in the popularity of golf which has been caused by multiple factors including lack of interest by younger generations, high costs, time commitment need to play a round, difficulty and lack of accessibility (Stinson, 2017). By January of 2018, the financial hardships and declining popularity of golf was worrisome enough that Toronto City staff commissioned a review of all municipal golf operations (Goffin, 2018).

The financial struggles of municipal golf courses have left the City at a crossroads. As the City of Toronto struggles to generate revenue and manage its operating budget, the idea of closing some golf courses has been suggested to remove the financial burden from the City's books (Goffin, 2018). Beyond financial issues, another frequently cited negative of the golf courses is that they have barriers to entry, remain closed for five months of the year and are not truly public lands. Municipal golf courses became a major issue in Toronto during the fall of 2018 as Toronto mayoral candidate Jennifer Keesmaat proposed closing three city-owned golf courses during her campaign (Draaisma, 2018).

Keesmaat was quoted as saying the current use of the golf courses doesn't represent good use of public land and the parcels of land can be opened up to "benefit far more people" (Draaisma, 
2018). She proposed converting the three closed golf courses into parkland, arts and cultural hubs, sports fields, outdoor skating rinks or new community centres (Draaisma, 2018). Taking the concept of redevelopment even further, Toronto could also follow the lead of many privatelyowned suburban golf courses in the Greater Toronto Area (GTA) which have closed in recent years and been sold to developers who have converted the land into housing subdivisions or condominiums (Noor, 2016).

There are however still many benefits to golf and the City of Toronto municipal golf courses. Golf is a popular sport enjoyed by roughly 5.7 million Canadians of all ages and genders (Golf Canada, 2017). Golf has also been scientifically proven to have positive health benefits such as improvement of both cardiovascular and respiratory systems (Parkkari, et al., 2000). These benefits are of particular importance to one of golf's largest demographic groups, seniors, to whom the sport is an effective form of exercise even at advanced ages where participating in most other sports is impossible.

Seniors are far from the only group that utilizes the courses as all five City courses run camps and programs for children allowing them the opportunity to learn golf (City of Toronto, n.d.). The courses are also affordably priced and accessible by public transit making them an excellent learning ground for beginners and those who do not drive. While golf may be associated with being an elitist sport, the City of Toronto golf courses and programs make the sport accessible to the middle and lower classes of the city. If the City owned golf courses were closed, it would make golf inaccessible to thousands of Torontonians who cannot afford expensive private club memberships or do not own a car to drive to public suburban courses. 
There is also a strong case to be made against redevelopment of the courses. All five City of Toronto golf courses are protected parkland, part of the City's ravine strategy and are located in designated floodplains (TRCA, 2018). On all five properties, all of or most of the land is regulated by the Toronto Region Conservation Authority (TRCA) making redevelopment tough and dependent upon acquiring permits from the TRCA. This in turn makes the properties less enticing to a developer and less likely to generate a financial windfall for the City. Redevelopment could also result in the loss of valuable urban green space which likely could never be reclaimed.

There are compelling arguments to be made for both keeping and closing the golf courses but the dilemma of what to do with municipal golf course lands requires a clear solution soon as Toronto is currently facing serious challenges. The city is currently facing a housing crisis on multiple levels with the average price of a house reaching $\$ 845,000$ in December of 2018 (Toronto Real Estate Board , 2019), rentals rates reaching all-time highs (Toronto Real Estate Board , 2018) and the waiting list for social housing reaching 181,000 people (Pagliaro, 2017).

Homelessness has also reached a crisis point in Toronto with the city opening multiple emergency temporary shelters to try and accommodate rising demand (Breen, 2018). In addition to housing issues, the city's public transit system is overcrowded and underfunded (Murthy, 2017) and parts of the city severely lack parks and greenspace (Pelley, 2015). These issues also come at a time when Toronto's population is rapidly growing, only putting further emphasis on addressing these challenges (Statistics Canada, 2017). With the supply of available land in Toronto continuing to shrink, the City will have to consider the role golf course lands could perhaps play in providing solutions to some of these problems. 
This paper will examine what specific adaptations can be made to publicly owned golf courses with a specific focus on two City of Toronto golf courses; Scarlett Woods and Dentonia Park. These two courses were chosen because they have frequently lost money in recent years and were two of the courses Jennifer Keesmaat proposed closing. Background research for this paper will focus on examining precedents of golf course redevelopment from around the globe as well as precedents of land subdivision, adaptive reuse, reprogramming of greenspace, buildings within parks and other examples that are relevant to this issue. A list of best practices will then be compiled and a framework incorporating the best practices will be created. This framework will then be used in two cases studies on the City of Toronto golf courses. From these case studies, recommendations will be drawn, and the outcome of this research should provide a clearer picture of what would be the most efficient and beneficial uses of public golf course lands for a municipality. 


\subsection{Overview of the Golf Industry and Golf in Toronto}

Before beginning the literature review and examination of precedents, it would be beneficial to give a brief history of golf in Toronto and examine the current state of the golf industry in the GTA. This overview will help to establish the opportunities and challenges facing the golf industry and provide a clear understanding of how we have arrived at this present moment where municipal golf courses are under review for closure or redevelopment.

\subsection{The History and Current State of Golf in the Greater Toronto Area}

Modern golf was invented in Scotland in 1457 but first came to Canada in the late 1800's and quickly grew in popularity with over 50 courses in operation by 1902 (Golf Canada, 2019). Toronto was amongst the first places in Canada to construct a golf course with the Toronto Golf Club, a private, members only club opening its doors in 1876 in the city's east end (The Toronto Golf Club , n.d.). Many other private golf courses such Rosedale, Lambton, St George's and Weston were constructed in the following decades and are still operational today (Score Golf, 2018).

For the first half of the $20^{\text {th }}$ century, golf in Toronto was reserved only for those who could afford the expensive memberships at private golf clubs as public courses did not exist. Private golf clubs are golf courses that can only be accessed by members of that specific golf club. These members pay an initiation fee and an annual fee which covers joining the club and the cost of playing golf at the club. Anyone without a membership must be a guest of a member if they wish to play. Public courses are the opposite; anybody who pays the daily rate know as a green fee may play the course and no membership fee is required. Public courses can be privately-owned or publicly owned like the City of Toronto courses are and can offer memberships, but they are not required. 
The absence of public golf changed in 1956 when the City of Toronto opened Don Valley Golf Course, the first municipal golf course in Toronto (Green, 2013). Golf course construction as an industry peaked in the 1960 's as golf became more accessible to the masses and Toronto was no exception to the boom in development (Golf Canada, 2015). By 1973, the City of Toronto had constructed two additional golf courses and acquired two formerly private golf courses to bring its total golf portfolio to five courses (City of Toronto, n.d.). All five of these courses were open to the public and required only a green fee to play. Outside of Toronto, golf courses both private and public began to appear alongside growing suburban towns in Mississauga, Pickering, Brampton and Richmond Hill.

Presently, there are 19 golf courses in operation within Toronto (City of Toronto Treasurer and City Solicitor, 2012). 12 of these courses are private golf clubs and all 12 are privately owned. Of the remaining seven public courses, five are city owned, two are owned by crown corporations and one is privately owned (City of Toronto Treasurer and City Solicitor, 2012). In addition, more then 100 golf courses both public and private are located within an hour's drive of Toronto providing GTA golfers with a variety of options (Golf Advisor, 2019).

These courses range in difficulty from professional caliber courses right down to small facilities designed for children and beginners. The courses also vary in price range. Private golf clubs in the GTA still require a membership ranging in cost from roughly $\$ 30,000$ - $\$ 100,000$ plus annual fees ranging between $\$ 2,000$ - \$7,000 (Grange \& Willis, 2018). These fees put private clubs out of the price range of most GTA residents however, most public courses are more affordable. The daily fee for a round of golf at the five City of Toronto owned courses ranges from \$27 $\$ 70.50$ depending on the course and the day of the week (City of Toronto, n.d.). Fees for other 
courses in the GTA can range from $\$ 25$ - $\$ 235$ again depending on the course, day of the week and time of year (Deegan, 2015).

Despite the large number of courses catering to all different skill levels and price ranges, golf is on the decline in Toronto and Canada. From 2009-2014, the number of rounds played in Canada declined by $10 \%$ and on the City of Toronto courses alone, a decline of $15.5 \%$ in rounds played was reported from 2007 to 2016 (City of Toronto , 2017). Another measure of the health of the golf industry is new course construction. From 2005-2015, Golf Canada identified that 158 courses had closed across Canada while only 17 new courses were under construction during that same period (Stinson, 2017). There is no one specific reason why golf is on the decline and multiple reasons are often citied including the sport being too time consuming, too costly, too difficult, requiring a car to access frequently and being boring to younger generations.

The biggest reason however, is the decline of the housing development/golf course model that was extremely popular in the 1980's and 90's and can be seen across North America (Stinson, 2017). This type of development was initially popular in the southern United States with gated communities of large single-detached homes being built surrounding a golf course (Lorinc, 2016). While the gated community concept did not catch on in the GTA, many Toronto area suburbs and retirement communities feature similar concepts including the presence of a golf course. The 2008 global financial crisis severely hurt the housing development/golf course model's economic viability and it has not fully recovered since (Stinson, 2017). The result has been a lack of new golf courses built and existing golf courses being closed and redeveloped into housing, a trend that is currently popular in the GTA due to the strong real estate market (Lorinc, 2016). 
The golf industry is aware of the decline and has began taking steps to boost the game's popularity. Some of these include encouraging shorter and easier courses, relaxing the rules, enlarging the size of the hole and even reducing the number of holes from the traditional 18 down to 12 or 9 (Stinson, 2017). Those trends and others can currently be observed at golf courses around the GTA. Altogether, golf is still popular in Toronto and GTA yet, the large number of courses in the area and current industry conditions will be tough to sustain over the coming years unless younger generations become more invested in the sport.

\subsection{Current state of City of Toronto Golf Operations}

The City of Toronto owns five public golf courses. Before examining the courses in-depth, it is important to note that while the City owns the land and collects revenue from these properties, it does not operate them. The current service delivery model for the five City operated golf courses is that golf course assets and turf are maintained by the City, while ticket sales, golf cart rentals, pro shops, lessons and programs as well as food and beverage operations are contracted out under two separate agreements (City of Toronto , 2017). These agreements cost the City roughly $\$ 346,000$ per year as of 2017 and have been hailed as an economically efficient move (City of Toronto , 2017).

The City courses are quite affordable with the price of a round ranging from $\$ 27-\$ 70.50$, well below the typical $\$ 60$ - $\$ 100$ fee charged at most public GTA courses. The City courses are also well used, because of their locations within the city boundaries and their accessibility by public transit. All five courses are kept in good condition and contain standard golf course amenities such as a parking lot, clubhouse, changerooms, practice facilities and liquor license. In addition, the courses all offer other common golf services such as golf lessons, clinics, camps for juniors and men's/women's leagues. While the City courses many not be as challenging or well 
kept as a private club nor have large and lavish clubhouses, they are equal to most public golf courses in the GTA.

Despite their location and affordability, the City golf courses have been no exception to the declining interest in golf. In 2016, 157,965 rounds were played at City of Toronto golf courses which represented a 15.5\% decline from 2007 statistics (City of Toronto , 2017). Revenue from the five courses, which usually hovers around the $\$ 5$ million range has also declined recently (City of Toronto , 2017). City golf operations ran at a loss every year from 2014-2017 with the losses ranging from as low as $\$ 74,000$ in 2016 to as high as $\$ 234,000$ in 2014 , a rainy summer (City of Toronto , 2017). It is important to note however that not all of the five City-owned courses lost money and these figures represent the sum of all five.

In addition to the yearly losses, $\$ 2.5$ million was spent on capital improvements during this same time period. These improvements could not be neglected as many addressed key health and safety priorities (City of Toronto , 2017). This will continue in the future as the City's Capital Plan has forecasted an additional \$9.7 million in capital improvements will have to be spent from 20182026, with most of the expenses again relating to health and safety requirements (City of Toronto , 2017). Overall, the financial picture for the City courses does not look promising.

City staff have however identified these problems and in a 2017 report, identified five potential areas of upgrade for the course (City of Toronto , 2017). While these upgrades would require capital, they would help the competitiveness of City courses. The five areas identified were, updated and digital/mobile booking systems and customer-facing technology to compete with current industry standards, collecting data for tailored marketing approaches, flexible fee structures that allow for demand-based pricing to ensure full utilization, updated and expanded facilities 
suitable for events and tournaments and updated food and beverage facilities and options (City of Toronto , 2017). Significant investment would be required for improved food and restaurant facilities and updated and expanded pro shop facilities (City of Toronto , 2017). Overall, City of Toronto golf courses are well used but face significant financially challenges due to declining interest in golf and high capital improvement costs. Despite this, City staff have identified ways to improve the golf facilities and potentially improve the economic situation of the Toronto's municipal golf courses.

\subsection{Overview of Golf Course Redevelopment in the Greater Toronto Area}

The past few years have brought a new trend to GTA golf: golf course redevelopment. As golf declines and land values rises across the GTA, suburban golf courses have become a target for developers looking to build and cash in on the lucrative GTA housing market. Since 2013, no fewer then six GTA area golf courses have either been sold to developers or are in the process of being converted into housing developments (Noor, 2016). Included in these six cases are York Downs Golf \& Country Club in Markham and Glen Abbey Golf Club in Oakville.

York Downs was a 167-hectare property containing two 18-hole golf courses (Noor, 2016). In 2015 , the club was sold to a consortium of developers for $\$ 412$ million with the purpose to be redeveloped into housing (Noor, 2016). The large economic windfall from this sale has certainly established that selling a golf property in the GTA for development is a lucrative financial deal. Glen Abbey is an 18-hole championship golf course that has held the Canadian Open 30 times and is one of Canada's most famous courses (Howes, 2017). Yet despite this history, its owner Clublink Corp, filed a development application in 2015 that would see parts of the course redeveloped into housing (Noor, 2016). While the Town of Oakville rejected the redevelopment 
plan in February of 2018, the Ontario Superior Court has ruled that the redevelopment of the course can proceed (Lea, 2018).

As demonstrated by these two examples, even financially successful and prestigious courses can be redeveloped in this current economic climate. The trend of golf course redevelopment will likely continue in the future as housing prices remain high and the number of golf courses in the GTA may sharply decline even more in the coming years. New golf course construction has slowed to an almost complete stop in the GTA meaning the supply of golf courses likely will not be replenished even as some are redeveloped. 


\subsection{Examination of Golf Course Adaptation and Redevelopment Options}

Now that the basic overview of the GTA golf industry has been established, this chapter will focus on what other jurisdictions have done regarding their golf courses. Many municipalities both in Canada and around the world have their own golf courses with financial troubles and they have come up with a variety of solutions to this problem. While the focus of this paper is on municipally owned courses, examples of privately-owned golf course redevelopment have also been included in this chapter as some are relevant. Through research, these solutions can be grouped into three categories each with their own unique characteristics: reuse, conversion and redevelopment.

\subsection{Reuse}

The closure of a golf course is often met with backlash both from local golfers and residents whose homes back onto the golf property. Adaptive reuse of the golf course, where the property remains as a golf course but incorporates additional uses can be used as an effective compromise. The simplest and most basic form of this is allowing alternate forms of golf to be played on the course. Disc or Frisbee golf, Footgolf and Fling Golf are all new, alternative forms of golf that don't require golf clubs or a dress code.

Implementing them at an existing golf courses requires little capital and does not disrupt regular operations as participants of these new forms of golf can play along side regular golfers. These alternative forms of golf also are aimed at attracting a younger demographic to golf courses which could help offset the lack of interest in traditional golf amongst younger generations (Sorensen, 2014). Some examples of cities experimenting with these alternative forms of golf include Toronto which offers Fling Golf at four of its five municipal courses (City of Toronto, n.d.) and Mississauga which offers Footgolf and Fling Golf at its BraeBen Golf Course (City of Mississauga, n.d.). 


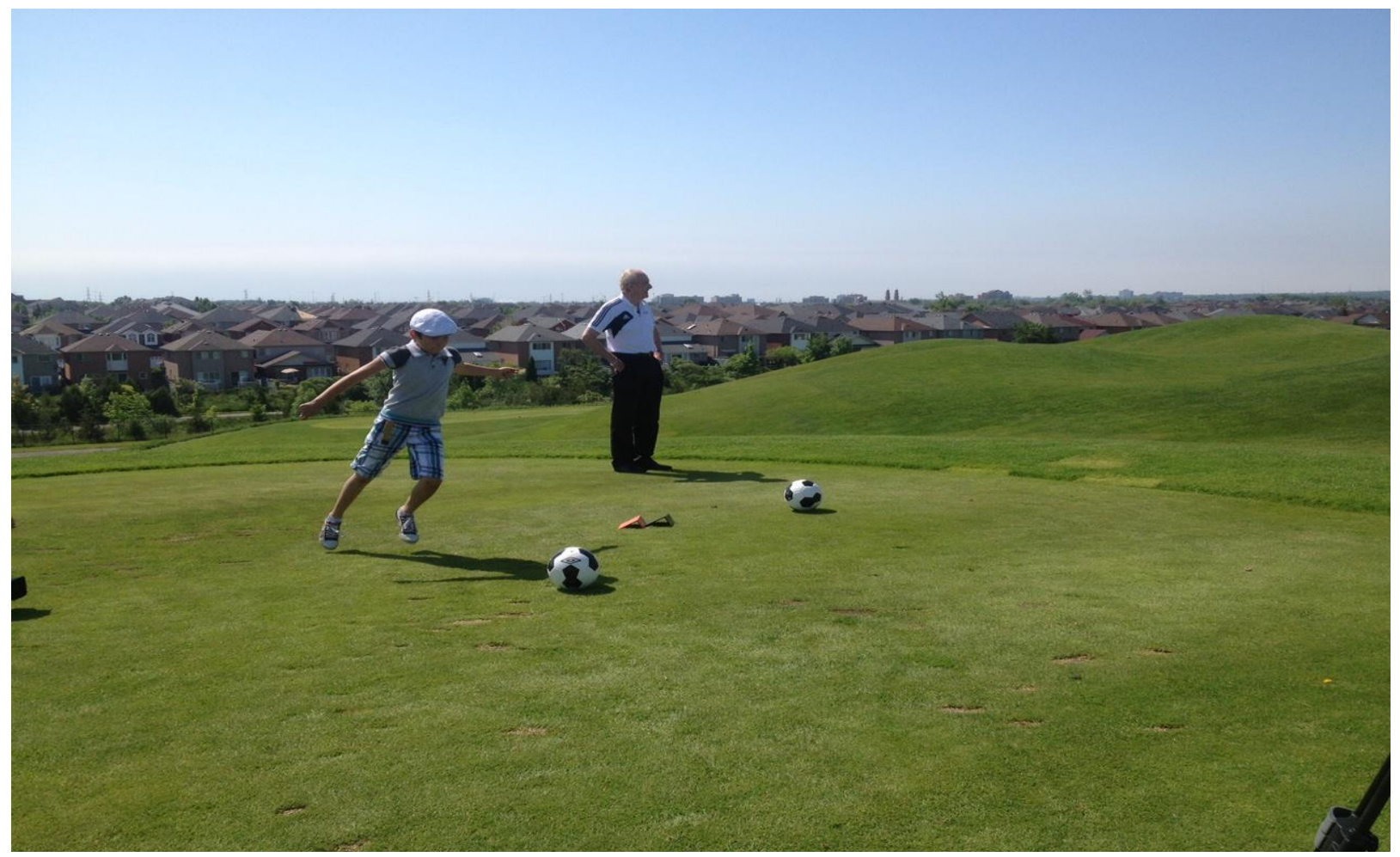

Figure 1: Child playing FootGolf at Mississauga's BraeBen Golf Course. (City of Mississauga, 2015)

Another simple adaptive reuse that makes golf courses a year-round facility is using the grounds for cross-country skiing, snowshoeing and other winter activities. Many Canadian cities including Edmonton (City of Edmonton, 2019) and Calgary (City of Calgary, 2018) currently design and maintain cross-country ski trails on their municipal golf courses. Use of the trails in these cities is free but users do have to bring their own equipment. The downside to this reuse is that it can only be done in cold weather cities that experience snow but in cities that have the climate, opening golf courses to skiers makes them a true year-round facility and if combined with equipment rentals and a snack bar, could generate revenue for a municipality.

One of the more inventive adaptations of a golf course can be seen at the University of Michigan in Ann Arbor on six Saturdays each fall. The University of Michigan plays its home 
football games in Michigan Stadium which seats over 107,000 people (Chiusano, 2018). To accommodate parking for that many fans, the University of Michigan Golf Course and the Ann Arbor Golf and Outing Club, both located across the street from the stadium, are turned into a parking lot and tailgating facility for the day of a game (University of Michigan, 2019).

A few minor rules such as restricting heavier vehicles and not allowing parking on playable golf surfaces such as greens and sand traps are in place but otherwise thousands of vehicles park on the course and leave promptly following the game allowing the course to reopen in time for regular operations on Sundays (University of Michigan, 2019). Rainy weather and snow do prompt closure of the golf courses as parking lots due to the damage that would occur to the course.

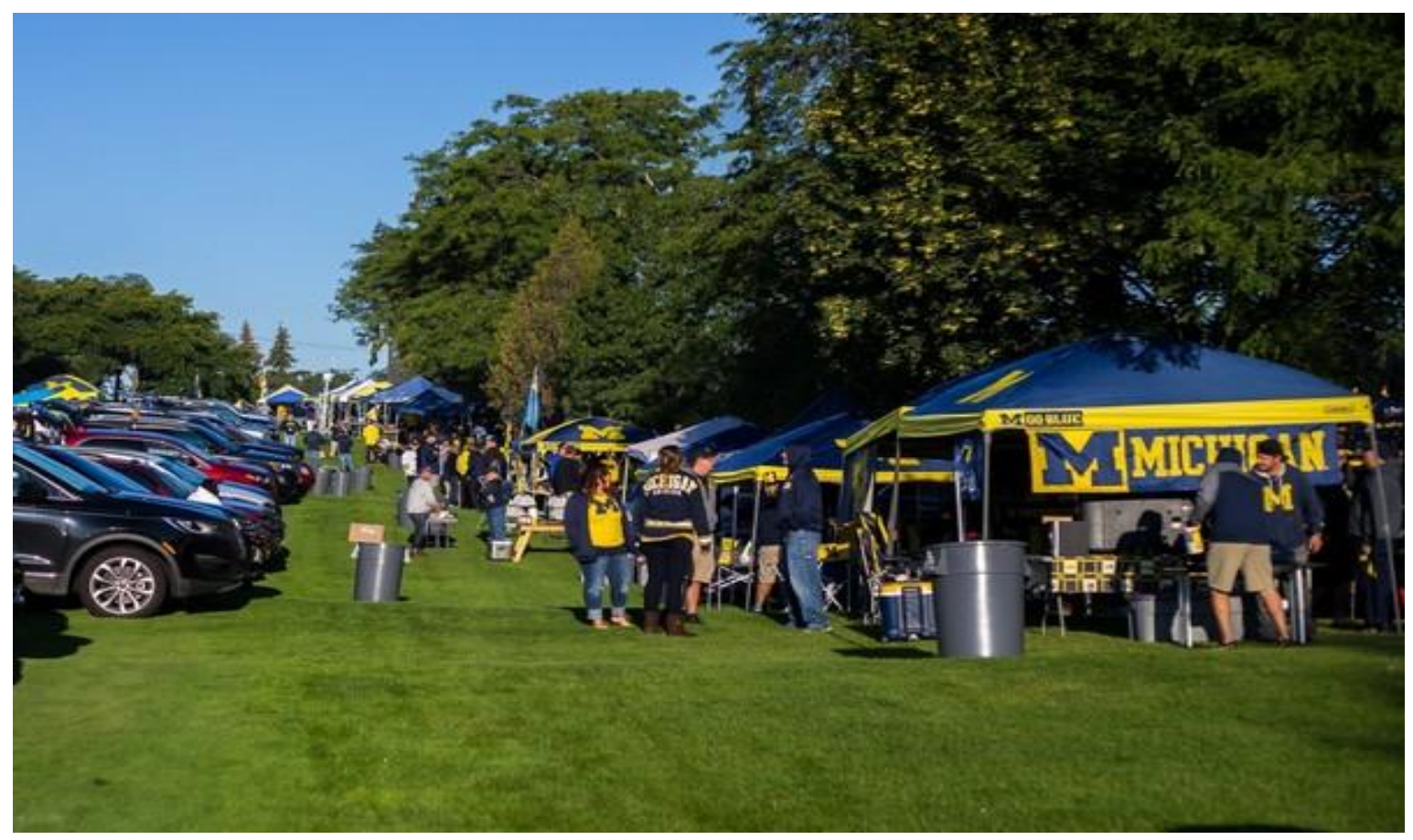

Figure 2: Tailgaters on the University of Michigan Golf Course. (University of Michigan , 2017) 
Another creative adaptive reuse was proposed in Kamloops, British Columbia in January of 2018. The municipality took over the McArthur Island Golf Course in October of 2017 after its owner decided not to renew the lease (Dickson, 2018). Since then, the course has sat empty while City sifts through proposals regarding the space (Dickson, 2018) including one to convert the course into a "tent city" for Kamloops homeless population (Dickson, 2018).

Kamloops was forced to open an additional temporary shelter in November 2017 but despite this, homelessness remained an issue (Dickson, 2018). Given the golf course's isolation from surrounding properties and the fact that the clubhouse currently has important amenities such as a water connection and washrooms, the golf course could be the perfect location for a tent city and help remove tent cities from other local parks. This is also not a permanent use meaning that should homelessness rates drop in Kamloops and a tent city is no longer required, the property could easily be converted back to a functional golf course.

\subsection{Conversion to Park or Natural Greenspace}

As discussed earlier, the conversion of golf courses into parks or other public greenspace is a popular idea. Some of the often-cited positives for doing this are:

- No barriers to entry: public parks are free and don't require a green fee or dress code

- Keeps the land as greenspace

- Environmentally friendlier: While golf courses are technically greenspace, they use pesticides and other environmentally unfriendly chemicals to maintain the appearance of the course.

- Low capital costs: Most of the infrastructure for a park is already present i.e.) washrooms, snack bar, walking paths, parking, etc... 
- Increases usage of land: Only a set number of foursomes can play on a golf course at one time. Many more people can enjoy a park at once.

- Space is more reprogrammable: Concerts, sporting events and plays can all be held in park but not on a golf course.

- Financial: Public parks often do not generate revenue but if a municipal golf course is not generating revenue either, then the land should be made accessible to all of the public as opposed to taxes subsidizing the operation of the course for which not all can afford to play.

Due to those reasons, converting golf courses to parks has become popular and there are already a few examples of this in the United States. In Atlanta, the Piedmont Park Golf Course closed in 1979 and the 70 acres of golf course land were added to the adjacent Piedmont Park (Piedmont Park Conservancy, n.d.). More recently, Huntsville, Alabama voted in 2017 to close its Becky Peirce Municipal Golf Course and convert it to a multi-use park featuring mountain biking trails and an elite level cross-country running course (Gattis, 2017). The conversion of golf courses to park is also not limited to municipalities converting their own municipal courses. Marin County, California purchased the San Geronimo Golf Course, a privately-owned golf course, in 2017 with the intent to turn it into a public park (The Trust for Public Land , 2017). 


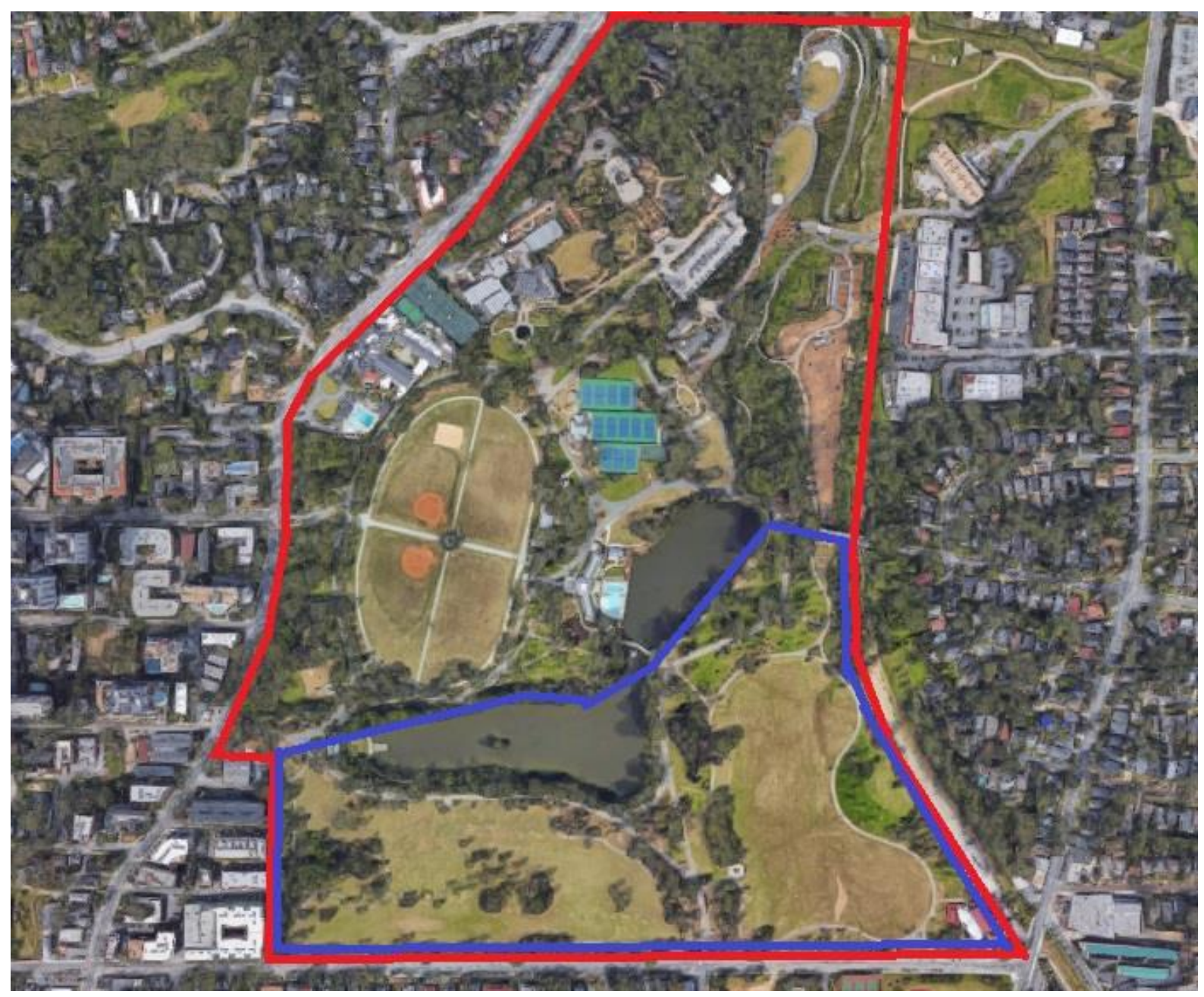

Figure 3: Piedmont Park in Atlanta, Georgia in 2019. The boundaries of the entire park are shown in red while the blue lines indicate where the former Piedmont Park Golf Course was located prior to its closing in 1979. The golf course lands were added to the public park lands following the closure of the golf course. (Google Earth, n.d.)

While those examples have involved completely closing the golf course, other golf courses have been reduced from 18 holes to 9 holes as way to compromise with local golfers but still provide additional public park space for the community.

An excellent example of this scenario is in Portland, Oregon, at the Colwood Golf Centre. The Colwood Golf Centre was previously a privately-owned golf course that was slated to be sold for industrial development given its proximity to the airport (The Trust for Public Land , 2016). The 
City of Portland however, did not want to lose greenspace in a part of town that had very little (The Trust for Public Land , 2016). To prevent this, the City purchased the property for \$5 million in 2014 (Giegerich, 2014) and rezoned the site to allow development on half the property and retain parkland on the other half (The Trust for Public Land, 2016). Included on the parkland side of the property is a 9-hole golf course which is owned and operated by the City and holds numerous programs which teach golf to disadvantaged youths in Portland in addition to being open for public play (The Trust for Public Land, 2016).

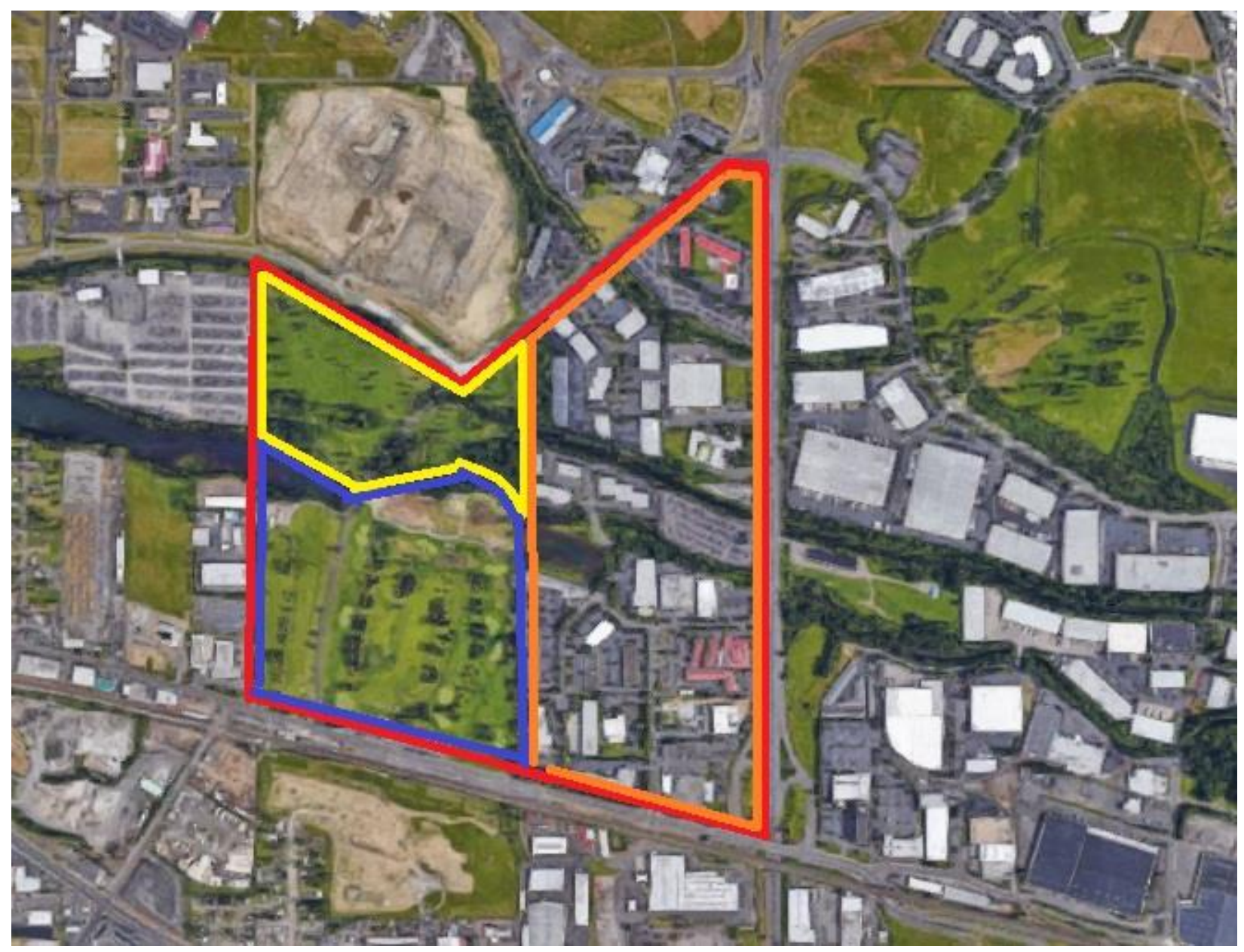

Figure 4: Former Colwood Golf Course Lands in Portland Oregon. The area with blue borders is currently the Colwood Golf Centre while the yellow bordered area is now a public park. The area with orange borders was the half of the property that was redeveloped for industrial uses.

(Google Earth, n.d.) 
Another creative conversion of a golf course can be seen in Deerfield Beach, Florida, where local residents opposed the redevelopment of an old golf course into housing (Allen, 2011). Residents wanted the least intrusive and quietest use for the land, so they proposed a cemetery (Allen, 2011). The developer eventually agreed and half the course was converted into a cemetery with the other half being turned over to the city and converted into a park containing a playground and playing fields, amenities lacking in Deerfield Beach which was originally built as a retirement community (Roberts, 2017). As this case illustrates, municipalities do not always have to purchase the golf course lands and can work with developers to ensure parkland and greenspace are provided in any redevelopment.

\subsection{Redevelopment}

Redevelopment is the final topic in this chapter and is a popular option especially amongst privately owned courses. Redeveloping a private course is easier as it does not involve the municipal politics required to close a municipally owned golf course. The members of a private golf club simply vote on whether they would accept of the redevelopment of their course and this determines approval. Redevelopment is often quite lucrative for members as the money received by a closing private club is distributed amongst its members.

Redevelopment has already occurred in the GTA with the sale of York Downs Golf \& Country Club to a consortium of developers who will turn the property into a housing development. Another popular redevelopment option is reducing the course from 18 holes to 9holes and selling the other 9 holes for development. An example of this can be seen at the Toronto Hunt Club, a private golf club in Toronto's east end which is now only 9-holes.

This concept is not limited only to privately-owned golf courses however. Pittsburgh and Wichita, Kansas are currently amongst the many cities considering selling golf courses to private 
developers. Thunder Bay sold one of its municipal golf courses in 2013 to a local developer who intended to construct a resort on the property (Smith, 2016). While the sale did provide an injection of cash to the City's budget, the sale was quite controversial with many Thunder Bay residents questioning the sale price and the bidding process (Judge, 2015). Nonetheless, Thunder Bay is currently looking at closing another one of its municipal golf courses with the intent to redevelop it into a housing project that will create additional revenue for the city (Smith, 2016).

Another option involving development is the subdivision of part of the golf course lands. By selling a parcel of land, the golf course can generate revenue far beyond what it would generate from golf related activities alone. Subdivision can take many forms ranging from selling nine holes and keeping the remaining nine for golfing to selling parcels of land that do not impact the golf course. An example of the latter is occurring in the GTA at the Ladies Golf Club of Toronto located in Thornhill, Ontario. In 2017, local developer Tridel bought a 2.6-acre parcel of land in the northwest corner of the golf course property (Craine, 2017). The land was sold for $\$ 23$ million and Tridel plans to develop two condominium towers on the site (Craine, 2017). Golfing was not affected at all by the loss of land and the $\$ 23$ million profit from the sale has put the Ladies Golf Club on solid financial footing for the future (Craine, 2017). 


\section{0: Additional Precedents}

Chapter Three examined precedents specifically involving golf courses. Chapter Four will review related cases that do not involve golf course lands. The subdivision of lands, adaptive reuse of urban greenspaces, programming of parks, economic tools and other relevant examples will be discussed.

The first scenario is the subdivision of lands. The scenario of selling a parcel of land on a golf course property was already shown in Section 3.3 with the example of the Ladies Golf Club of Toronto selling 2.6 acres of its property to a local developer. The examples of subdivision examined in this chapter will instead look at churches which provide some creative and pertinent examples of subdivision. Churches across Canada have seen their attendances dwindle in recent years leaving them unable to pay bills and perform upkeep on their facilities (Dixon, 2018). As a solution, many churches have sold portions of their property in order to raise the funds necessary to remain operational. In many scenarios, this involves selling off an unused part of the church grounds, but other instances are more innovative and applicable to golf courses.

Christ United Methodist Church in St Petersburg, Florida sold its parking lot to a developer for \$5.6 million in 2018 (Ann-Moore, 2018). Selling a surface parking lot would have no disruption on the golf course itself and can raise funds but would create a shortage in parking as many golfers drive to the course and most municipalities have minimum parking requirements for golf courses. These problems could be potentially solved by reconstructing the parking below grade or relaxing the minimum parking requirements for golf courses. Urban golf courses such as the five owned by the City of Toronto are well connected to public transit and reducing parking could be justified. The land previously occupied by parking could then be used for any number of 
public uses such as schools, hospitals, community centres or parks and as mentioned, revenue from the sale would help solve financial issues.

Other churches have dealt with lower attendances by downsizing. This method requires selling the main portion of the church and moving the church operations into a smaller portion of the building. The Riverdale Presbyterian Church in Toronto, which was faced with a dwindling congregation sold the main portion of its church to developers who converted the space into townhouses in 2017 (Dixon, 2018). The church then took the money from the sale and renovated their remaining space in the building into a smaller worship space more suited to the smaller congregation (Dixon, 2018). Other churches such as Deer Park United Church in Toronto have sold their entire building and joined a nearby congregation turning two congregations into one (Gee, 2017). In the case of Deer Park United Church, the church building itself will be retained and converted into amenity space for a 28-storey condominium being built on the site (Gee, 2017). 


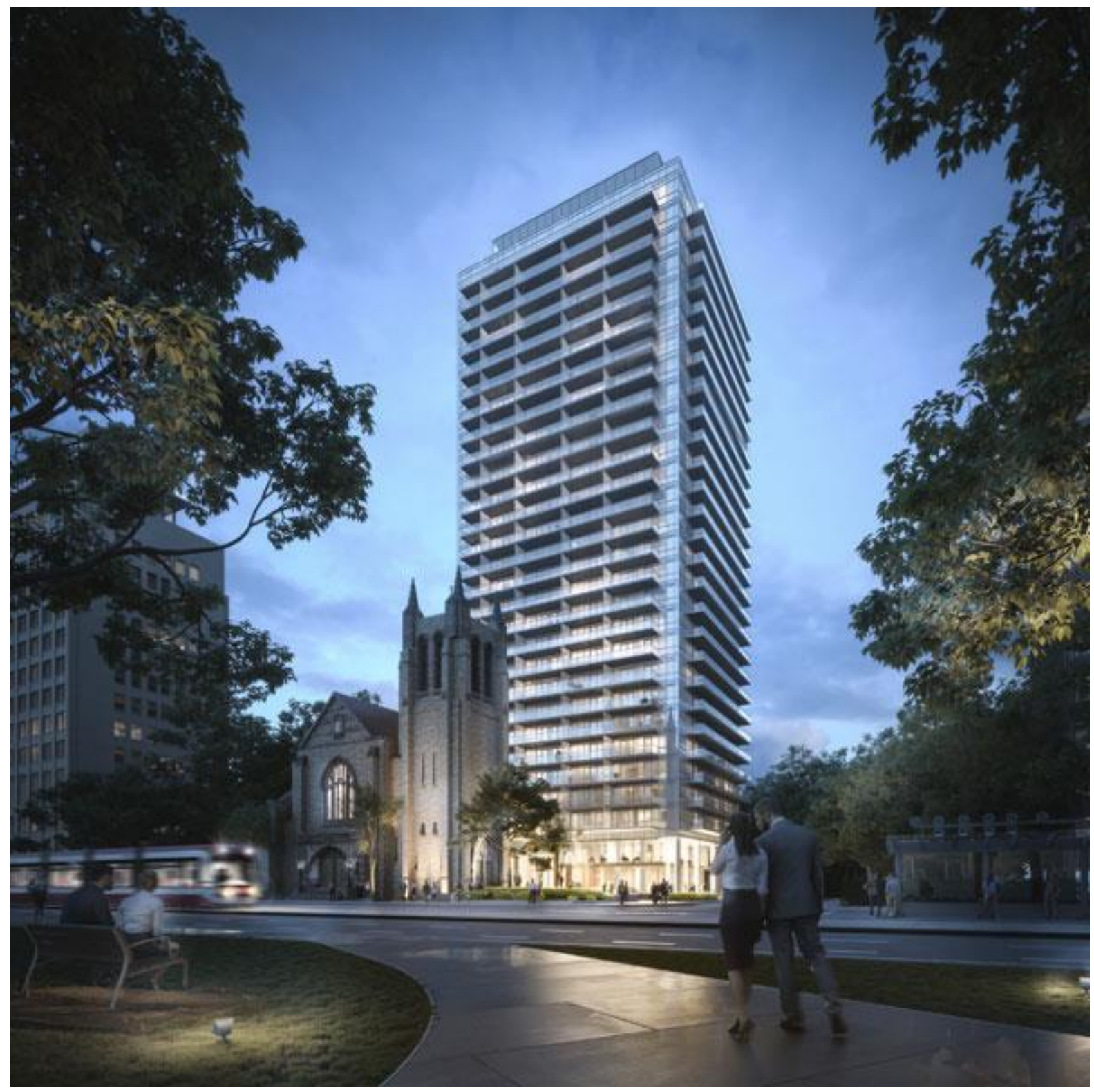

Figure 5: Deer Park United Church in Toronto, Ontario. The underused church was sold to a developer who is constructing a 28-storey condominium on the property but retaining the original church building. (Camrost Felcorp \& Diamondcorp, n.d.)

Golf courses could consider similar downsizing projects involving their clubhouses. Underused parts of the clubhouse such as restaurants, conference rooms, locker rooms and others could be sold off or converted to other uses while keeping the necessary elements of a clubhouse such as washrooms and a pro shop operational. Golf courses could also consider selling their 
clubhouse and building a smaller scale clubhouse elsewhere on the property or selling the air rights above the clubhouse for development. While constructing a new clubhouse may be problematic in terms of proximity to the parking lot or the first hole, the potential benefits both public and financial of selling the clubhouse could outweigh these inconveniences.

The second scenario involves urban agriculture. Urban farms and community gardens have been found to benefit their surrounding neighbourhood by welcoming involvement, physically improving degraded space, producing healthy local food, and creating employment opportunities (Poulsen, Neff, \& Winch, 2017). Urban farms also do not require much space or capital costs and can even generate small amounts of revenue from food sales. The McQuesten Urban Farm in Hamilton, Ontario measures only 3 acres in space yet its community impact is immense as it provides employment opportunities and access to nutritional food for the surrounding low-income McQuesten neighbourhood (McQuesten Urban Farm, n.d.). Adding an urban farm or community garden to a golf course would increase public benefit and have a very small impact on the golf course itself. A typical urban golf course is usually between 110 and 120 acres in total size (Crownover, n.d.) meaning that an urban farm the size of McQuesten would take up roughly $2.5 \%$ of the total golf course land.

The community of Serenbe, Georgia, located just outside of Atlanta presents an interesting example of a subdivision that was not built around a golf course but around an organic farm instead. Serenbe would seem the ideal location for a golf course given its warm climate, suburban location and relative proximity to Atlanta, however the roughly 200 acres needed to build a golf course was not feasible for Serenbe's developer (Grooms, 2010). Instead, the developer chose to construct an organic farm as the open space amenity for the community (Grooms, 2010). The Serenbe Organic Farm measures 25 -acres in size, cost roughly $\$ 50,000$ to build and has a large 
community impact through its weekly farmers markets (Grooms, 2010). The farm has also been attributed to higher property values in the Serenbe community. Serenbe was found to command up to $200 \%$ premiums over its neighbouring communities and statistics from across the USA have found similar results when comparing communities with urban farms to their neighbouring communities that are farmless (Grooms, 2010).

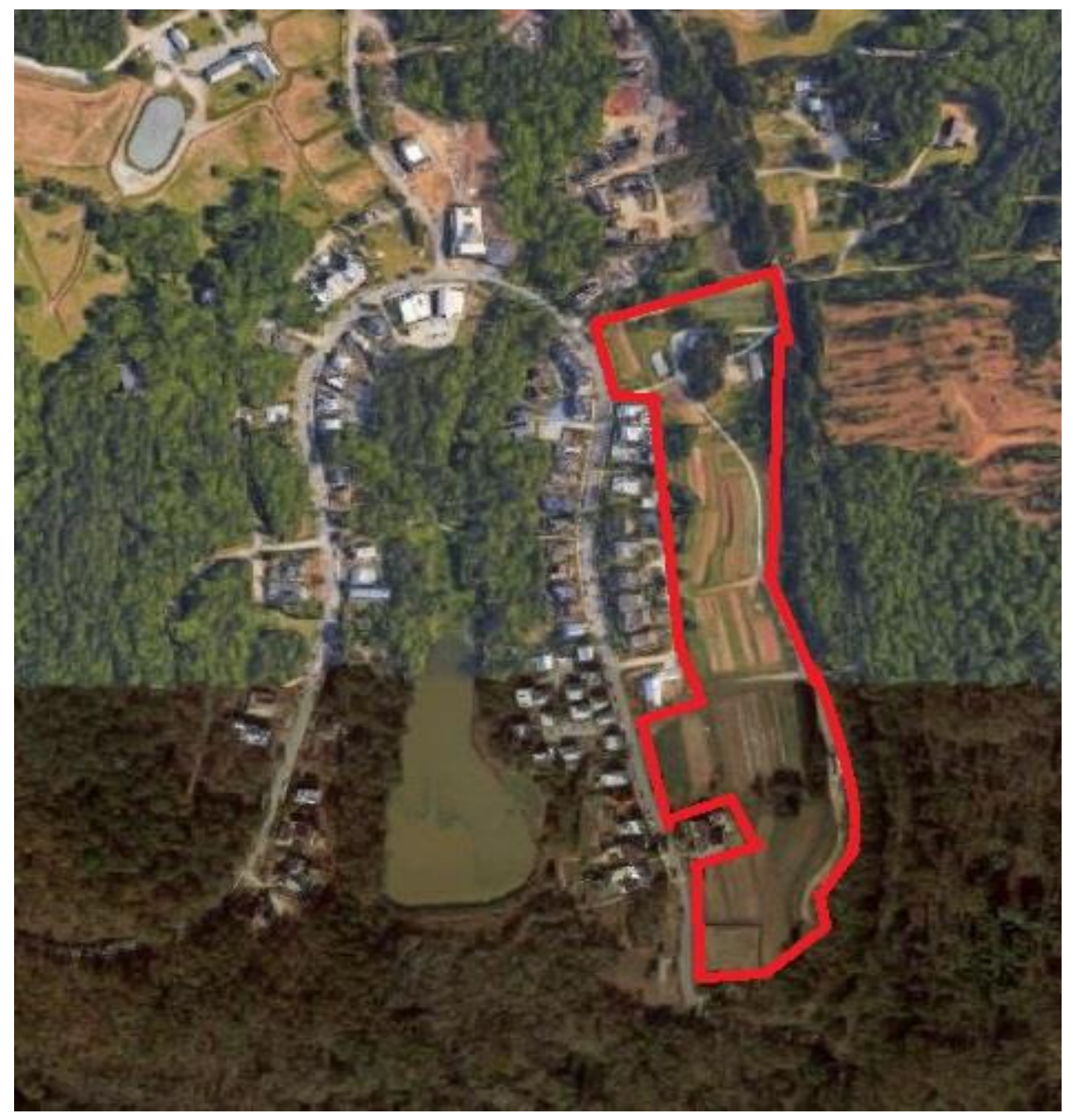

Figure 6: Serenbe Organic Farm in the community of Serenbe, Georgia. An urban farm, outlined in red above, was chosen instead of a golf course as the open space amenity for the community. (Google Earth, n.d.) 
The third scenario in this chapter expands on the idea of a tent city that was proposed for a closed, municipal golf course in Kamloops and is discussed in Chapter Three. The idea of a tent city can be taken a step further with the clubhouse serving as an overnight shelter during summers and a full-time shelter during colder months. Most golf courses have operational hours from roughly 5am until 10pm during peak summer months leaving the clubhouse unoccupied during the nighttime when temperatures decline and most homeless people seek shelter. Citizens using the shelter could leave the premises prior to the golf course opening in the morning and golf related activities would not be affected at all. In the winter time, the clubhouse could serve as a shelter for a full 24 hours, seven days a week. Golf course clubhouses are also generally isolated from surrounding properties by the golf course itself which would alleviate some of the concerns surrounding homeless shelters such as noise and loitering.

The isolation of the clubhouse and golf course is another advantage that could be utilized to bring more public benefit to the property. Potential uses such as music venues, bars/nightclubs, light industrial shops and others could take advantage of the isolation of the golf course and use the grounds during the nighttime or off-season. These uses are often associated with noise, pollution, crowds and traffic concerns however, the isolation and large size of a golf property and the presence of on-site parking would help alleviate some of these issues. Incorporating these uses would generate more revenue for the courses and open the spaces year-round to the public. These proposed uses also would not damage the golf facilities and golf activities could continue without disruption.

There are no examples of golf courses experimenting with these potential uses thus far, however parks already employ some of these uses quite successfully. High Park, in Toronto is home to a restaurant, zoo, museum and nature centre (High Park Toronto, n.d.). High Park also 
hosts Shakespeare in High Park, a series of Shakespeare plays performed at the High Park Amphitheatre during the summer months (Festivals Toronto, n.d.). All of these uses help animate the park and bring a variety of users of all ages to the park throughout the year. While no golf course is as expansive as High Park's 399-acres (High Park Toronto, n.d.), golf courses could incorporate one or two additional uses to their property to increase public access and public benefit.

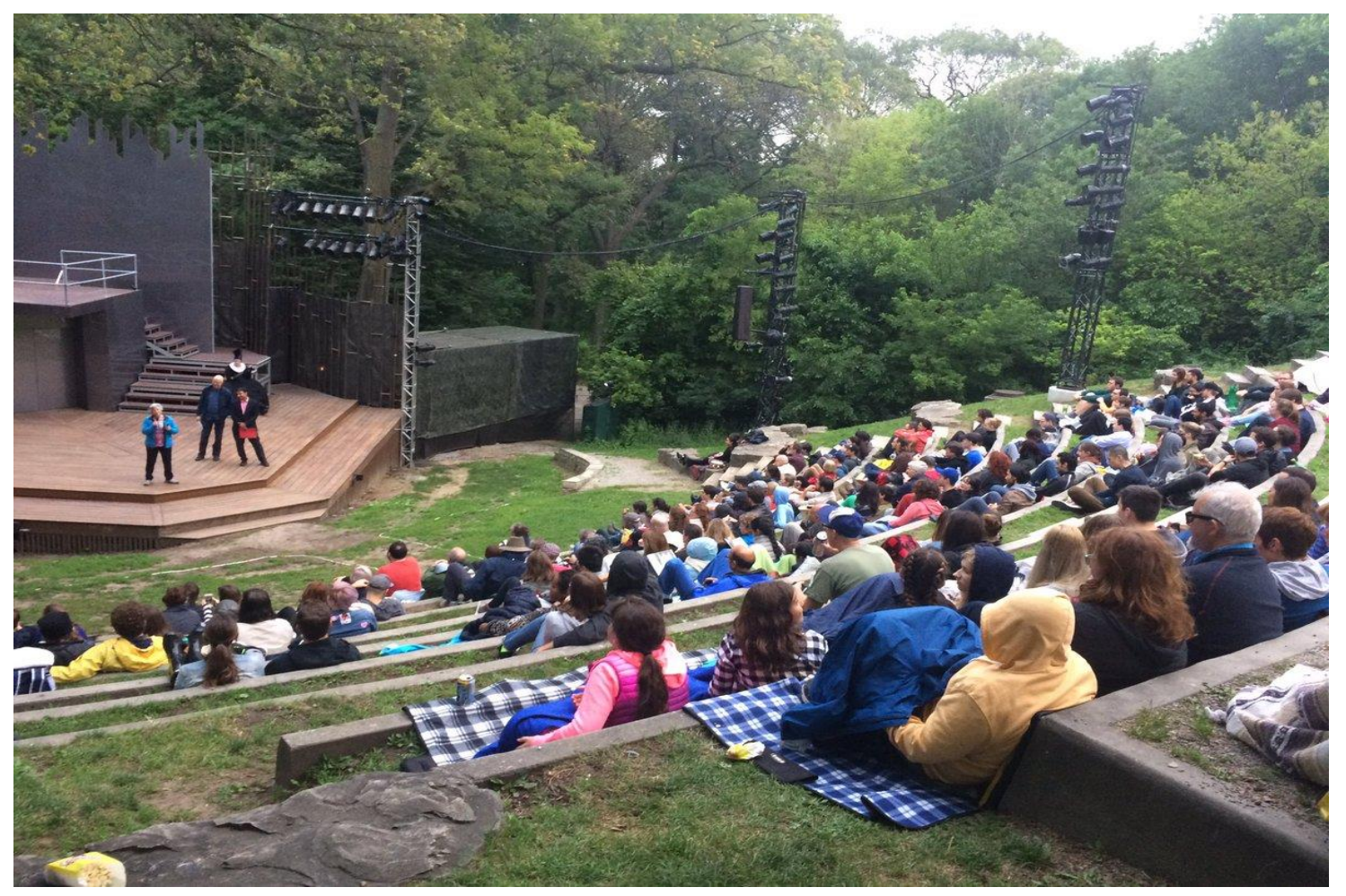

Figure 7: High Park Amphitheatre in Toronto, Ontario. (Canadian Stage, 2017)

A way of testing some of these additional uses could be through pop-up parks or temporary installations. A pop-up park is a small park space usually containing some of the traditional elements of a park such as grass, trees or benches and is temporarily constructed on a nonrecreational piece of land such as a parking space or a road. Installing an amphitheatre or industrial workshop may be too bold or costly a venture for many golf courses, however bringing those uses in for a temporary period such as weekends only would be more manageable. 
Pop-up parks have been installed in multiple Canadian communities recently as a form of community engagement. In July 2017, the City of Hamilton installed a pop-up park at Rebecca and John Streets by placing AstroTurf and benches on a parking lot destine to become a permanent park. Citizens were able to explore the park and provide feedback on what they would like included in the permanent installation. Montreal tried a similar approach with a pop-up park located at 962 Mount Royal Avenue East. Formerly a gas station, the site was staged with three different proposals of what a permanent park on the site might look like. Each proposal's basic layout was installed with wooden planks on the site for six weeks and residents were invited to give feedback on which proposal they preferred.

Finally, if development of any type is determined as the best course of action for a municipal golf course, economic tools like public land leasing should be considered to provide benefit for the general public. By keeping the land in public hands, the municipality will benefit from the increasing land values while also retaining control of the land uses. Municipalities could also generate revenue from the property in the form of annual rent payments that could be used to fund other important services and programs throughout the municipality. 


\subsection{Best Practices}

Chapters Three and Four have examined a number of precedents. From this information, Chapter Five will establish the best practices for municipal golf course adaptation. The best practices are general and should be considered regardless of what type of golf course adaptation is proposed. Ideal golf course adaptation should include all the best practices identified in this chapter however, this is not possible as each municipal golf course situation is unique and requires sitespecific solutions. There is no all-encompassing blueprint that can be applied to every municipal golf course that has financial struggles but based off the research outlined in the previous chapters, good municipal golf course adaptation should incorporate some of the following practices such as increasing public benefit, retaining greenspace, permitting off-season activities, permitting activities during non-peak hours, retaining public ownership of the land and encouraging activities that attract a mix of age groups:

- Increased public benefit

Golf courses are currently very rigid in who is allowed on the property and for what purpose. Only paying customers can access the golf course, restaurant, pro shop and other amenities providing a barrier of entry to those in the public who cannot afford or wish to play a round of golf. Given that public golf courses receive taxpayer money, they should offer services or uses on site that can benefit all of the public and barriers to entry should be removed. While golf courses must generate revenue and cannot offer free rounds of golf, they can decrease the barriers to entry and increase public benefit in multiple ways. The conversion of golf courses to a public park or recreation facilities would achieve this goal. Other less permanent and capital-intensive uses could be as simple as a pop-up park or allowing the golf course to function as a park during the winter. 
- Retain greenspace

Major urban areas such as Toronto lack in public greenspace and this need will only further be accentuated in the coming years as more urban dwellers reside in apartments and condominium units which do not have backyards (Attfield, 2017). Golf courses currently are not the truest form of public greenspace due to their barriers to entry and man-made landscaping, yet they are not built-form and do provide a habitat for plants and animals. Regardless of whether a municipal golf course is completely redeveloped for housing, converted into a park or only undergoes minor changes, greenspace must be retained on the site.

\section{- Permit off-season activities}

Golf courses in most parts of Canada are only open from mid-April until mid-October. In order to achieve maximum public usage of these facilities, golf courses need to offer activities and services during the five months of the year they are closed for golf. Depending on the use, this could also bring additional streams of revenue to the golf course. Some basic examples of achieving this would include opening the golf course for use as a public park or cross-country ski trail during the winter.

\section{- Permit activities during non-peak hours}

Golf courses only operate roughly from 5am until 10pm during peak summer hours when days are the longest. This leaves a minimum of seven hours daily where the property is unused. As irregular work situations become more common and night economies grow in many large cities, public lands should also be in use for as many hours as possible. Golf courses are no exception to this and could use clubhouse space functioning as a homeless shelter or 24-hour daycare to serve the public around the clock. 
- Retain as much of the land as possible in public ownership.

Given how valuable land has become in large global cities, many municipalities have examined selling public lands to gain profits. While this does provide a short-term windfall, the wiser move would be to retain the land and use methods such as public land leasing to profit from development on the property. Retaining public ownership of golf course lands would provide a municipality with control over the land uses, an annual revenue stream from ground rent and future flexibility. While this may not be possible in smaller municipalities where developers will not build on public land leases, larger cities such as Toronto can certainly leverage their land assets including golf courses.

- Encourage activities on the property that will attract a mix of age groups

The decline of golf has been in part caused by millennials and younger generations not taking up the game and by older generations who avidly golf dying out. Golf course adaptation should strive to bring a mix of age groups to the golf course to providing the facility with a more stable

cliental base that will last for many years and will help improve finances. This can be done by offering alternative forms of golf, shortening and simplifying the golf course to allow for shorter rounds or permitting other uses on golf course lands such as a restaurant or daycare.

\subsection{Framework}

In addition to the best practices, the adaptation of golf courses can be sorted into a framework containing three categories: reuse, conversion and redevelopment. These three categories best differentiate the most common adaptations of golf courses as there are clear distinctions between all three in the level of golf operations present on the subject site. For instance, in the reuse category, the golf course would not be altered in any way. Other parts of the property 
maybe be altered or sold, and the golf course may not remain operational seven days a week, but the actual playing features of the golf course would not be removed. In the conversion category, golf facilities may or may not be present on the property, but greenspace in the form of a golf course, park, natural preserve or other form must be present. The redevelopment category is similar as golf facilities may no longer exist on the property. In this case however, retaining part of the property as a greenspace is not a requirement and the entire property could be redeveloped.

This format was chosen to reflect the dynamic needs of modern cities. Some cities may be hesitant to close a money-losing golf course due to stiff public opposition while other cities may not be able to develop their golf courses due to environmental concerns. By using the three categories method, municipalities can decide what level of adaptation they would like to pursue and can then apply the best practices to that specific course of action.

Table 1 helps provides a visual guide of the best practices within the three-category framework. Each of the six best practices are listed under each category and then shaded in either green, yellow or red to show the level of priority they represent within that category. For instance, in the conversion category, retaining greenspace is shaded green as the major priority of the conversion category is converting the golf course to park space. As another example, in the redevelopment category, permitting activities during non-peak hours is shaded red. This is because having these types of activities are not a major priority and would likely be discouraged should the golf course be redeveloped into a residential neighbourhood.

It is also important to note that measuring these best practices is difficult. There are no proven criteria established thus far for measuring indicators such as public benefit. For the best practices like increased public benefit, evaluation would be done at a high level examining if there 
are more public uses on the golf course lands in general. For other best practices such as encouraging a mix of age groups or retaining greenspace, statistics and other forms of hard data will be used for evaluation. For instance, the amount of park space added to the golf course lands can be calculated quite easily and would determine how well greenspace was retained on the site.

\begin{tabular}{|c|c|c|c|}
\hline & \multicolumn{3}{|c|}{ Golf Course Framework } \\
\hline Priority Level & HIGH & MEDIUM & LOW \\
\hline Category: & Reuse & Conversion & Redevelopment \\
\hline $\begin{array}{l}\text { Golf Course } \\
\text { On-Site: }\end{array}$ & Yes & Maybe & No \\
\hline \multirow[t]{6}{*}{$\begin{array}{l}\text { Best Practices } \\
\text { Applicable: }\end{array}$} & Increase Public Benefit & Increase Public Benefit & Increase Public Benefit \\
\hline & Retain Greenspace & Retain Greenspace & Retain Greenspace \\
\hline & $\begin{array}{c}\text { Permit Activities During } \\
\text { Non-Peak Hours }\end{array}$ & $\begin{array}{c}\text { Permit Activities During } \\
\text { Non-Peak Hours }\end{array}$ & $\begin{array}{c}\text { Permit Activities During } \\
\text { Non-Peak Hours }\end{array}$ \\
\hline & $\begin{array}{c}\text { Permit Offseason } \\
\text { Activities }\end{array}$ & $\begin{array}{c}\text { Permit Offseason } \\
\text { Activities }\end{array}$ & $\begin{array}{c}\text { Permit Offseason } \\
\text { Activities }\end{array}$ \\
\hline & $\begin{array}{c}\text { Encourage Mix of Age } \\
\text { Groups }\end{array}$ & $\begin{array}{c}\text { Encourage Mix of Age } \\
\text { Groups }\end{array}$ & $\begin{array}{c}\text { Encourage Mix of Age } \\
\text { Groups }\end{array}$ \\
\hline & $\begin{array}{c}\text { Retain Public Ownership } \\
\text { of Land }\end{array}$ & $\begin{array}{c}\text { Retain Public Ownership } \\
\text { of Land }\end{array}$ & $\begin{array}{c}\text { Retain Public Ownership } \\
\text { of Land }\end{array}$ \\
\hline
\end{tabular}

Table 1: Best Practices of Golf Course Adaptation Framework. 


\subsection{Case Studies of City of Toronto Municipal Golf Courses}

Chapter Six will examine the cases of Scarlett Woods Golf Course and Dentonia Park Golf Course, both City of Toronto owned municipal golf courses. These courses were selected because they are municipally owned, have lost money in recent years and are two courses that have been proposed for closure and conversion to parks and community space (Draaisma, 2018).

These case studies will provide a brief overview of each golf course and its planning context followed by an examination of what adaptations could be made to the courses. The three categories from the framework; reuse, conversion and redevelopment will all be applied to each course to provide some concepts of what adaptation of these golf courses might look like.

\subsection{Scarlett Woods Golf Course Context}

The first case study will be Scarlett Woods Golf Course. Scarlett Woods is located at the corner of Jane Street and Eglinton Avenue in Toronto's west end. The executive length 18-hole golf course is a par 61 and measures 3749 yards in distance making it much shorter then the average GTA golf course (City of Toronto, n.d.). This has made Scarlett Woods popular with beginners and juniors who find it challenging but also with more advanced golfers who enjoy the affordability and short length of time it takes to complete a round. Green fees at Scarlett Woods range from $\$ 36$ - $\$ 43.50$ and it is important to note that it only takes roughly three and half hours to play a round at Scarlett Woods as opposed to the four hours plus normally seen at full-length GTA golf courses (City of Toronto, n.d.).

On the Scarlett Woods property are many of the standard golf course amenities such as a clubhouse, pro shop, fully-licensed restaurant, changerooms, washrooms, practice facilities and a 107-space parking lot (City of Toronto, n.d.). Scarlett Woods is also easily accessible by public transit with multiple bus stops located beside the property. 


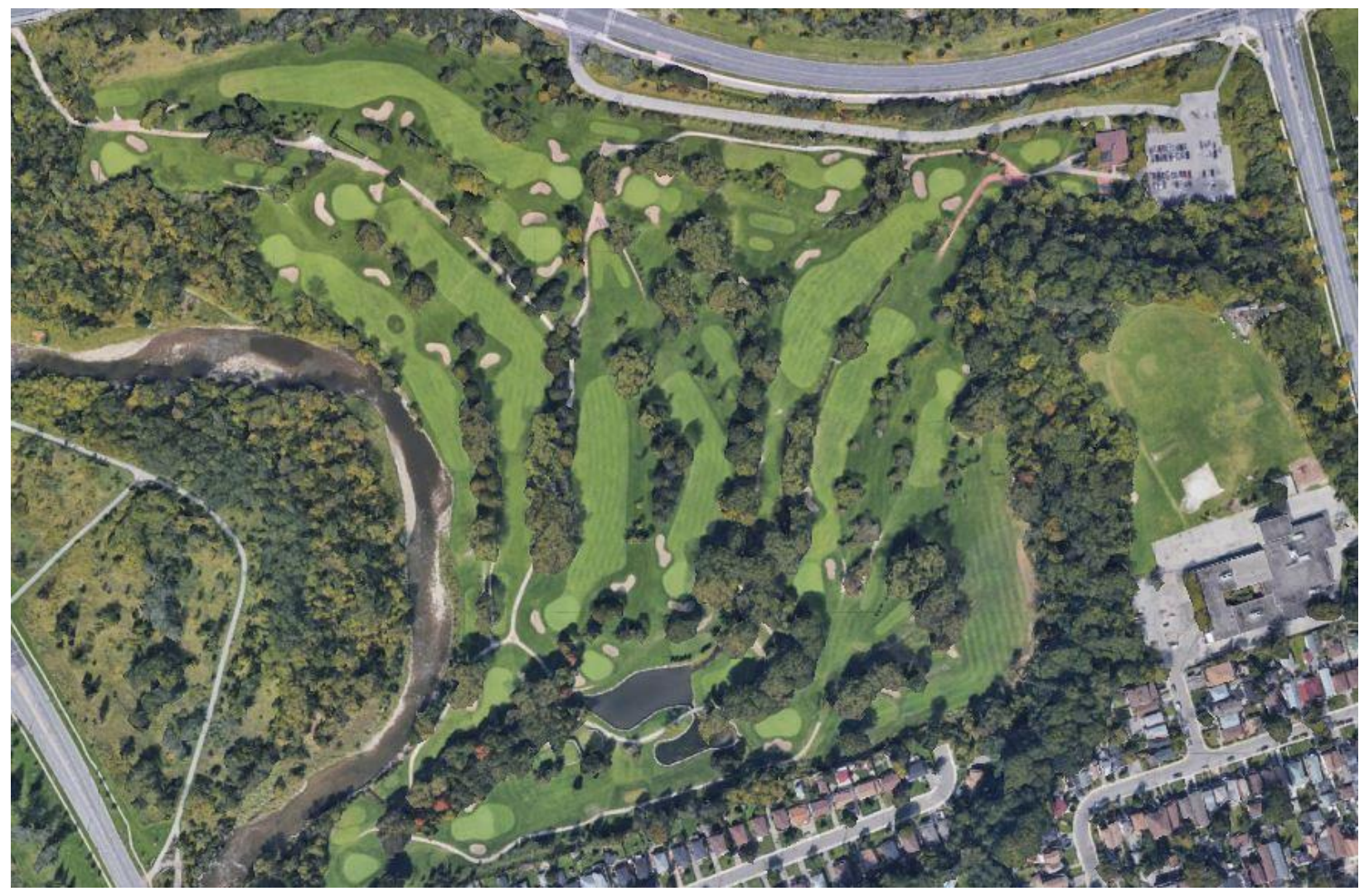

Figure 8: Aerial View of Scarlett Woods Golf Course. (Google Earth, n.d.)

Financially, Scarlett Woods has been no exception to the decline of golf in Toronto. In 2005 , 38,015 rounds were played at the course. By 2015, this number had fallen to 27,749 representing a decline of $27 \%$ over the decade (Cain, 2016). As expected, revenues also fell and by 2011, Scarlett Woods posted a profit of only $\$ 23,000$, down from $\$ 99,000$ in 2007 (Cain, 2016). While more recent financial documents are not available, Scarlett Woods has likely posted net losses in recent years. Financial hardship, the short length of the course which caps green fees at a low figure and the course's excellent location to downtown Toronto have made closing Scarlett Woods a very real possibility. 


\subsubsection{Site Context}

The Scarlett Woods property is 58.3 acres in size and is part of the Rockcliffe- Smythe neighbourhood. The golf course occupies the southwest corner of the Jane and Eglinton intersection and is bordered by the Humber River to the west and by public parks to the north. The golf course borders on a residential neighbourhood to the south with a large wooded hill separating the golf course from an elementary school along the eastern boundary of the property.

The Rockcliffe-Smythe neighbourhood is home to 22,246 people and is a diverse, working class neighborhood featuring a mix of apartment neighbourhoods, employment zones, parks and low-density residential neighbourhoods (City of Toronto Social Policy, Analysis \& Research, 2018). Rockcliffe-Smythe has distinct socio-economic issues and was identified as a Neighbourhood Improvement Area by the City of Toronto in their Toronto Strong Neighbourhoods Strategy 2020 (TSNS 2020) (City of Toronto, n.d. ). TSNS 2020 is the City of Toronto's action plan for ensuring that each of Toronto's 140 neighbourhoods can succeed and thrive (City of Toronto Social Development, Finance \& Administration , 2019). It identified 31 neighbourhood improvement areas which the TSNS 2020 aims to improve by strengthening the social, economic and physical conditions and delivering local impact for city-wide change through the activation of people, resources and neighbourhood friendly policies (City of Toronto Social Development, Finance \& Administration , 2019).

Statistics that illustrate the issues facing Rockcliffe-Smythe include its Median Household Income, which is $\$ 54,908$, approximately $\$ 11,000$ below the City of Toronto average and that the percentage of residents with a bachelor's degree or higher is only $18.2 \%$ compared to the Toronto average of 44.1\%. (City of Toronto Social Policy, Analysis \& Research, 2018) The neighbourhood 
did however rank similarly to the City-wide average in many other housing, language and immigration statistics (City of Toronto Social Policy, Analysis \& Research, 2018).

\subsubsection{Planning Context}

In Toronto’s Official Plan, Scarlett Woods has a land use designation of Other Open Space Areas (Including Golf Courses, Cemeteries, Public Utilities). Lands with this designation are to be used primarily for golf courses, cemeteries, and open spaces associated with utilities and other specialized uses and facilities. The Official Plan generally prohibits development in Parks and Open Space Areas with the exceptions of recreational and cultural facilities, conservation projects, cemetery facilities, public transit and essential public works and utilities where supported by appropriate assessment. Additional Official Plan information can be found in detail in Appendix A.

The City of Toronto Zoning By-law 569-2013 zones the property as Open Space - Golf Course. Open Space - Golf Course Zone, like the Official Plan, is very restrictive of what is permitted. The complete list of permitted uses and permitted uses with conditions pertaining to Open Space - Golf Course Zones can be found in Appendix B, however some of the important permitted and conditionally permitted uses for $\mathrm{OG}$ zoned lands are parks, club, eating establishment, educational use and personal service shop. The maximum height for the property is 14.0m or 4 storeys. The property is also not subject to any Secondary Plans or site-specific policies.

From an environmental standpoint, Scarlett Woods is located in a floodplain and the entire property is Toronto Region Conservation Authority (TRCA) regulated land as can be seen in Figure 9. Under Ontario Regulation 166/06, the TRCA regulates and may prohibit work from taking place within valley and stream corridors, wetlands and associated areas of interference and the Lake Ontario waterfront (TRCA, 2004). Development is not strictly prohibited on TRCA 
regulated lands; however, any development would require a permit issued by the TRCA that is granted upon a review of the development plans. This process would apply to any proposed development on the Scarlett Woods property and Appendix C contains further information regarding TRCA regulations and the TRCA Living Cities Policy which details why the TRCA regulates land.

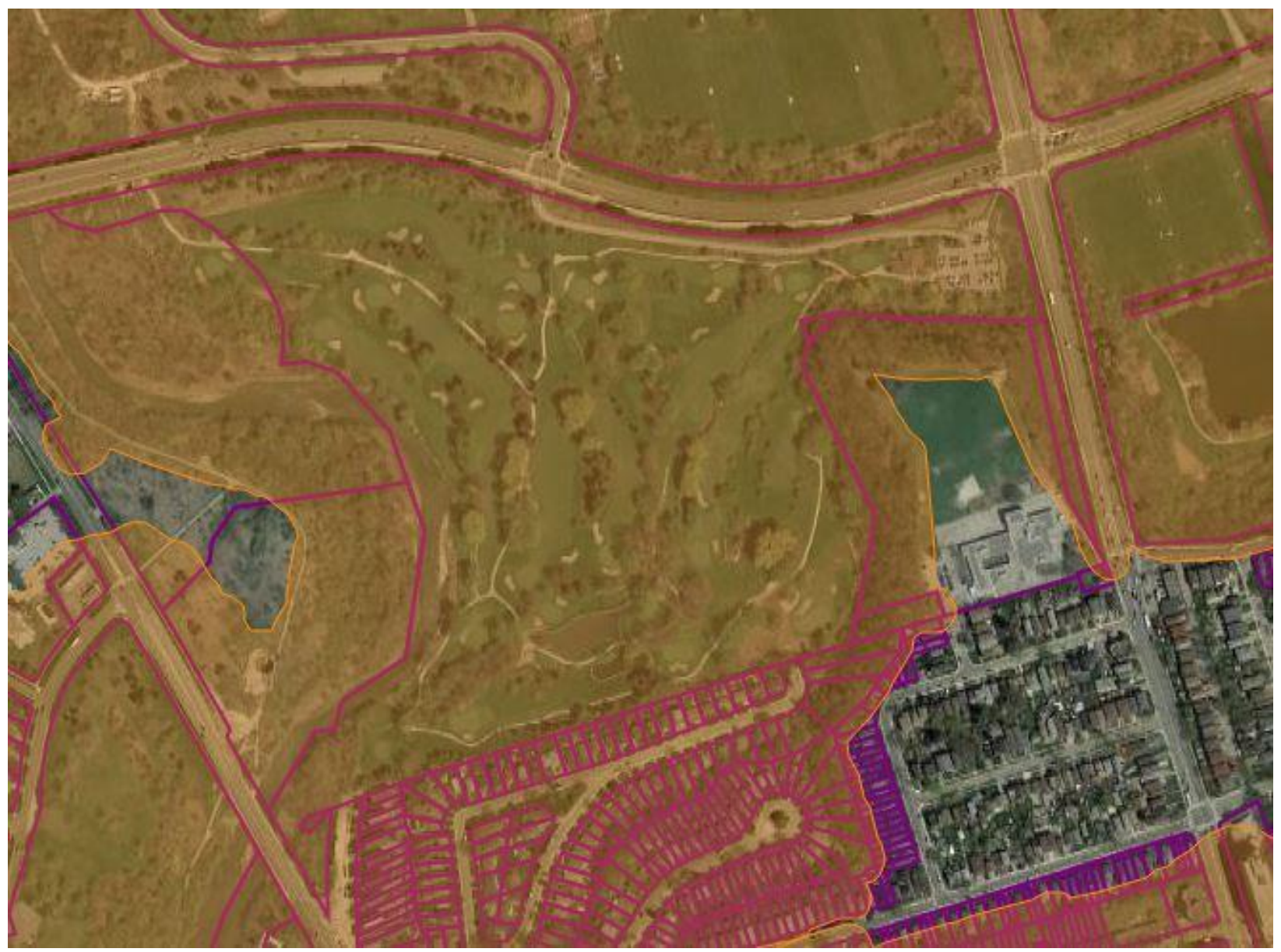

Figure 9: Map of TRCA Regulated Lands near Jane and Eglinton. TRCA regulated lands can be seen in orange. Scarlett Woods can be seen in the middle of the image and the property is entirely TRCA regulated land. (TRCA, 2019)

In addition to all these policies, the Jane and Eglinton corridor may undergo significant change in the coming years with both the Jane Street LRT and the western extension of the 
Eglinton Crosstown LRT passing through the intersection and creating a major transportation hub for western Toronto (Toronto Transit Commission , 2018). The future of both lines remains uncertain due to political and funding issues however, any long-term development on the Scarlett Woods site should consider the potential presence of these transit lines in the future and be planned accordingly.

\subsubsection{Reuse Scenario}

The first proposed adaptation scenario will be the least intrusive and would see only minor changes made to the property. Given the zoning and height restrictions on the site and the fact that Scarlett Woods is located in TRCA regulated land, a large-scale redevelopment is unlikely and smaller more reasonable changes may be the appropriate way to accomplish the best practices of golf course adaptation. In this scenario, the golf course at Scarlett Woods would remain functional and the playing features of the course such as greens and tee boxes would not be significantly altered. Additional uses and functions would however be added to the course and the course may not remain operational seven days a week.

To illustrate this, the following four changes could happen. Scarlett Woods already offers Fling Golf but it could offer additional alternative forms of golf such as DiscGolf and SoccerGolf to help attract additional customers, specifically those who don't own golf equipment or have no interest in taking up the sport. In addition, during the offseason, Scarlett Woods should remain open as a public park and weather permitting, allow cross-country skiing and other winter activities to take place on the course. The damageable elements of the golf course such as the greens, tee boxes and sand traps are already tarped over and protected during the winter so the golf course would not suffer permanent damage from these additional activities. 
The creation of an urban farm could also be implemented at Scarlett Woods. While the Rockcliffe - Smythe neighbourhood and the adjacent Mt Denis neighbourhood are not food deserts, having an additional source of healthy produce and a unique community space would be beneficial and help achieve the TSNS 2020's goal of activating people and resources. While most of the Scarlett Woods property is comprised of playing features for the golf course such as greens, fairways, rough, sand traps and etc..., there are some areas that do not factor into the golf course layout and could be converted. These excess lands are shown in the Figure 10 below.

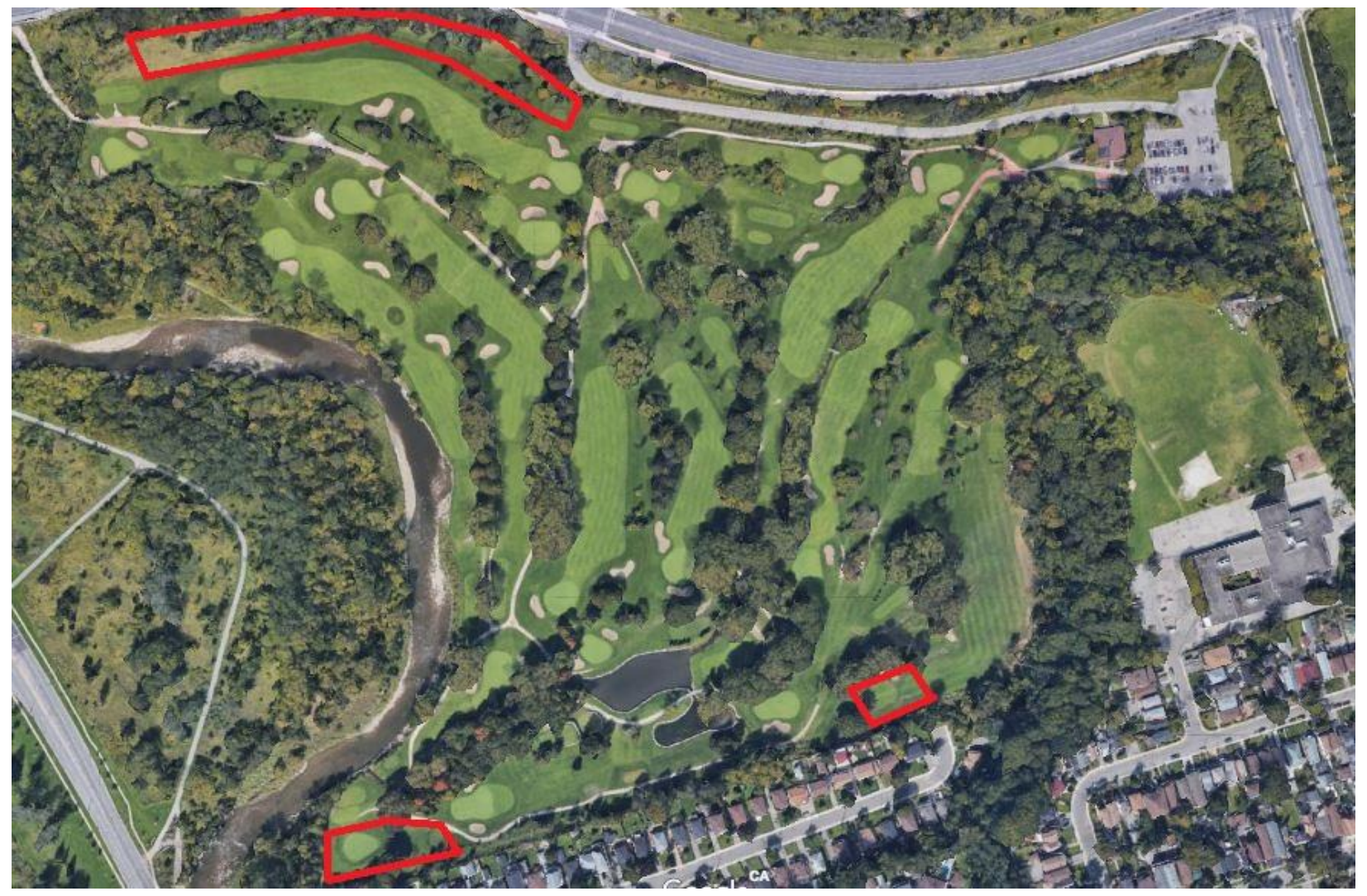

Figure 10: Potential Urban Farmland at Scarlett Woods. The excess lands that could be converted to urban farmland are shown in red. (Google Earth, n.d.)

The lands highlighted above total 3.11 acres in size, roughly the same as the McQuesten Urban Farm in Hamilton which has brought immeasurable community benefit as detailed in Chapter Four. A rezoning of the property or a Zoning By-law Amendment would be required 
however as agriculture uses are not permitted in Open Space - Golf Course Zones. Agriculture uses are permitted in Open Space - Natural Zone which is a similar zone.

If the northernmost parcel of land property highlighted in red above were severed from the Scarlett Woods property and rezoned to Open Space -Natural Zone, then an urban farm could be created on that parcel. This rezoning would have no effect on golf activities at Scarlett Woods and the property would remain in the ownership of the City.

The final use that should be considered are pop-up parks and temporary installments. An urban farm or any permanent infrastructure investment could be considered to costly or drastic a change to be approved by government. In this case, pop-up parks and temporary uses could be implemented instead. These installments could occur during the offseason or off-peak hours in order to minimize the disruption of golf related activities. The temporary nature of these installments and their low capital costs allow for a variety of different uses to be showcased perhaps catering to the distinct needs of the surrounding community. Temporary uses would also be simple to implement as the City of Toronto already has a permitting system for parks and recreational facilities.

Overall, the reuse scenario incorporates many of the best practices identified earlier such as retaining greenspace, attracting a mix of age groups to the property, increasing public benefit and allowing off-season activities. These options have low capital costs and only the urban farm would require a rezoning of a portion of the property. In addition, these proposed adaptations could further the strategies in the TSNS 2020 for Rockcliffe-Smythe by activating people and resources. An example of what the property might look like incorporating these new uses can be seen in Figure 11. 


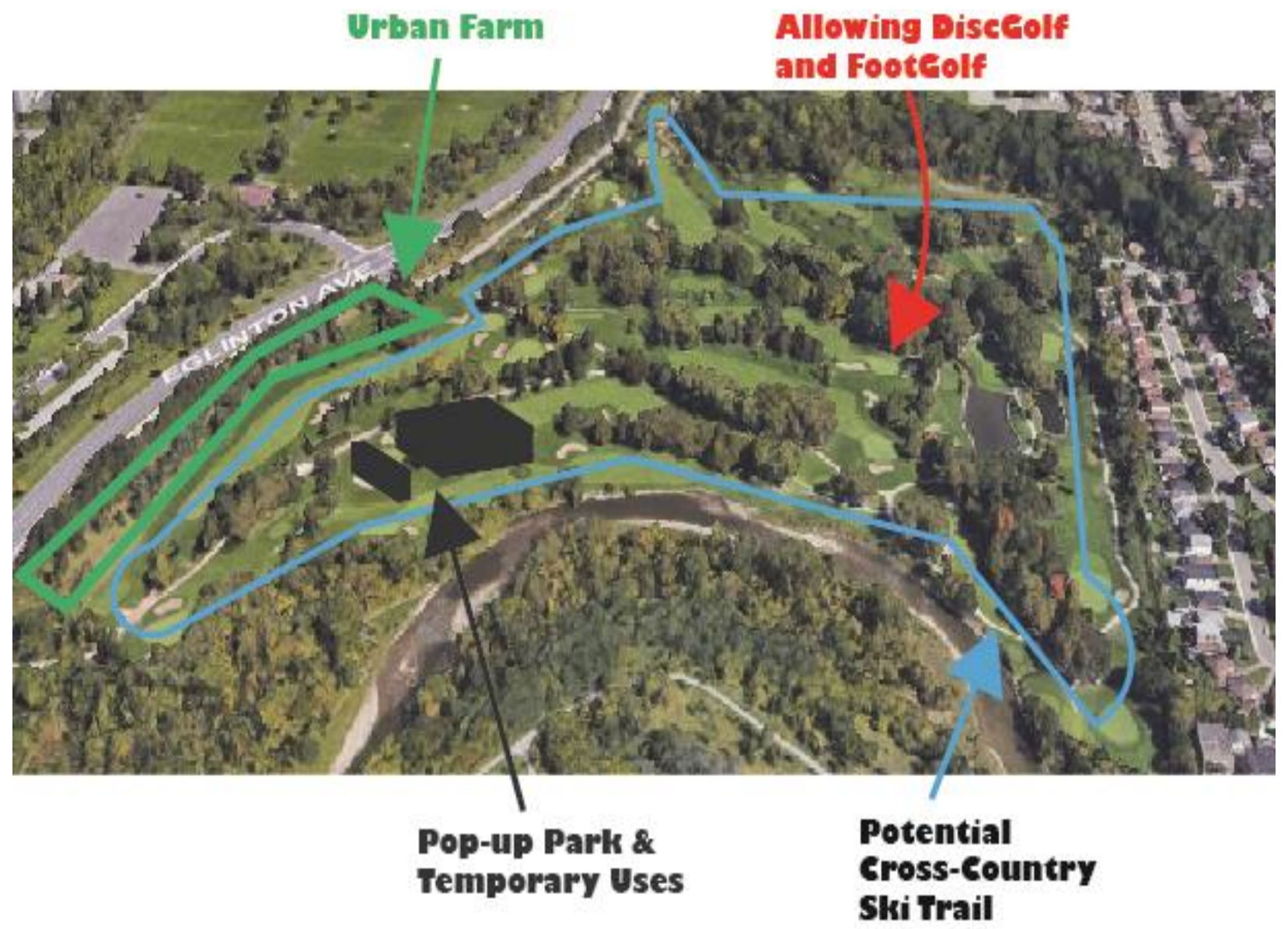

Figure 11: Example of Scarlett Woods Incorporating New Uses. (Google Earth, n.d.)

\subsubsection{Conversion Scenario}

The second proposed scenario will build on the proposal to convert Scarlett Woods into a public park. While no site plans or conceptions have been released to date, this section will show two different ways Scarlett Woods could be turned into a park. The first example involves keeping nine holes and converting the remaining nine to a public park. An example of what this would look like can be seen in Figure 12. 


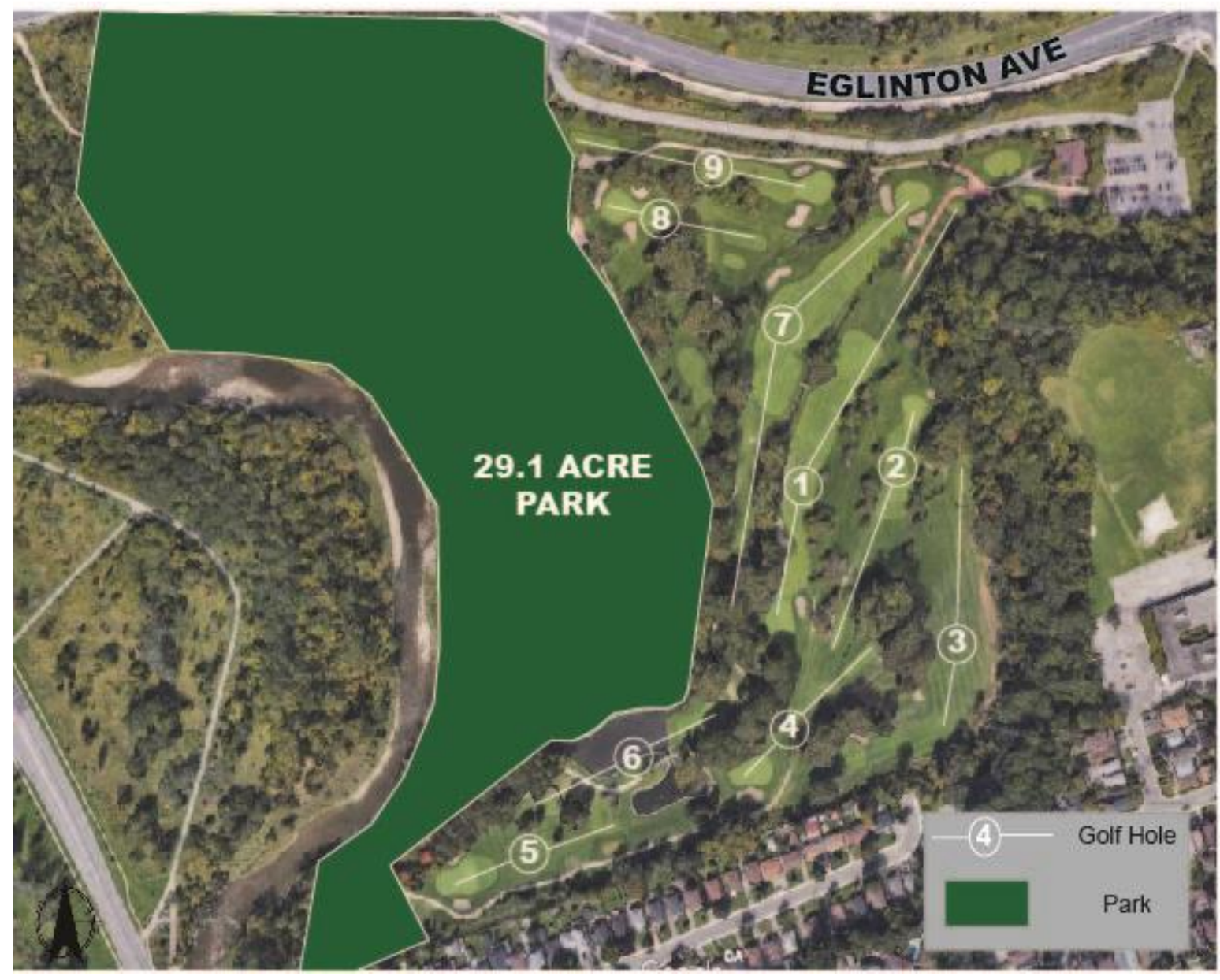

Figure 12: Proposed Conversion of Scarlett Woods to Public Park and 9-hole Golf Course. (Google Earth, n.d.)

This option would create a park roughly 29.1 acres in size on the Scarlett Woods property. It could also be connected to the adjacent Eglinton Flats park on the north side of Eglinton Ave by a passage beneath the road. The golf course would be reduced to nine holes by keeping the current $1^{\text {st }}, 2^{\text {nd }}, 3^{\text {rd }}, 4^{\text {th }}, 5^{\text {th }}, 9^{\text {th }}, 10^{\text {th }}, 17^{\text {th }}$ and $18^{\text {th }}$ holes of the course. The clubhouse, parking lot and practice facilities, located in the upper northeast corner of the property would also all be kept.

The other option would see the entire property converted into a 58.3-acre park. In this case, golf activities would cease to exist on the property. The clubhouse could be retained and some of 
its current uses such as a restaurant could remain operation or the clubhouse could be repurposed and become a community space or serve other functions. The parking lot could also be retained to meet the minimum parking standards required for parks in the City of Toronto by-laws. Both this option and the "9-hole" option would require rezoning from Open Space - Golf Course Zone to Open Space - Recreation for the portion of the property that would become a park.

The conversion scenarios shown in this section both represent an implementation of the best practices of golf course adaptation. Either scenario would retain the entire property as greenspace and would provide increased public benefit through the addition of the public park which would also be a year-round facility attracting residents of all ages to the property. The option of retaining 9 holes on the property would also help satisfy local golfers by providing them with a place to play and the sport would not be removed completely from the area.

\subsubsection{Redevelopment Scenario}

The final scenario that will be examined is a redevelopment scenario. Redevelopment of the Scarlett Woods property would be a very difficult and unlikely task given the entire course is located in TRCA regulated lands. While development is not prohibited on TRCA regulated lands, Scarlett Wood's proximity to the Humber River and the fact that almost the entire course is in a designated floodplain make it unlikely the TRCA would approve a large-scale development. The property would also require a rezoning and an Official Plan Amendment if uses such as residential or commercial were to be built on the property. 


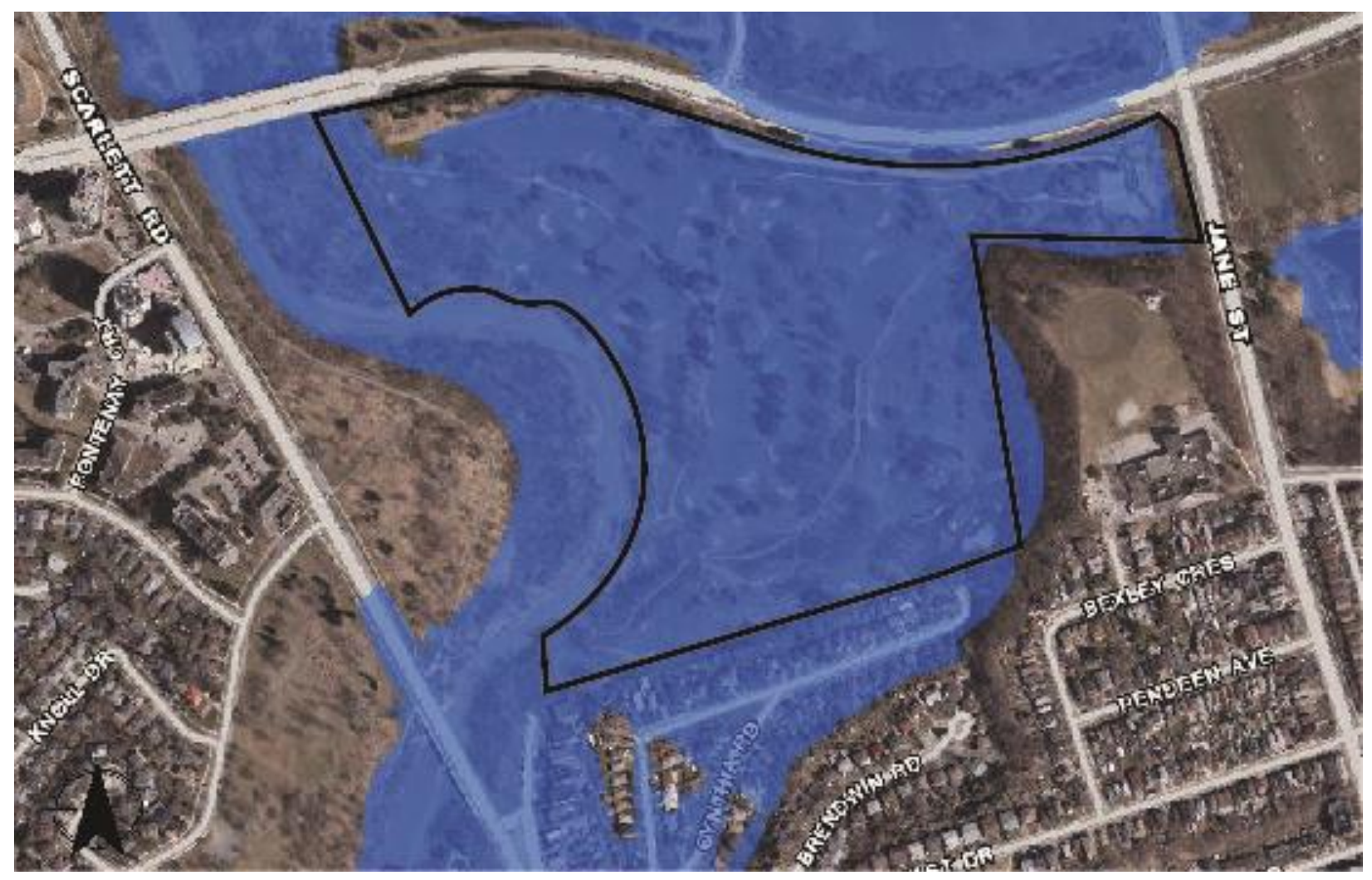

Figure 13: Map of TRCA Designated Floodplain Lands. The Scarlett Woods property is outlined in black. (TRCA, 2018)

Instead of a housing subdivision on the course, the redevelopment of the clubhouse and parking lot will be examined. These areas are still TRCA regulated lands and in a TRCA designated floodplain but the fact that they are already developed and are the part of the property furthest from the Humber River make them the most developable part of the property. This part of the property can be seen in detail in Figure 14. 


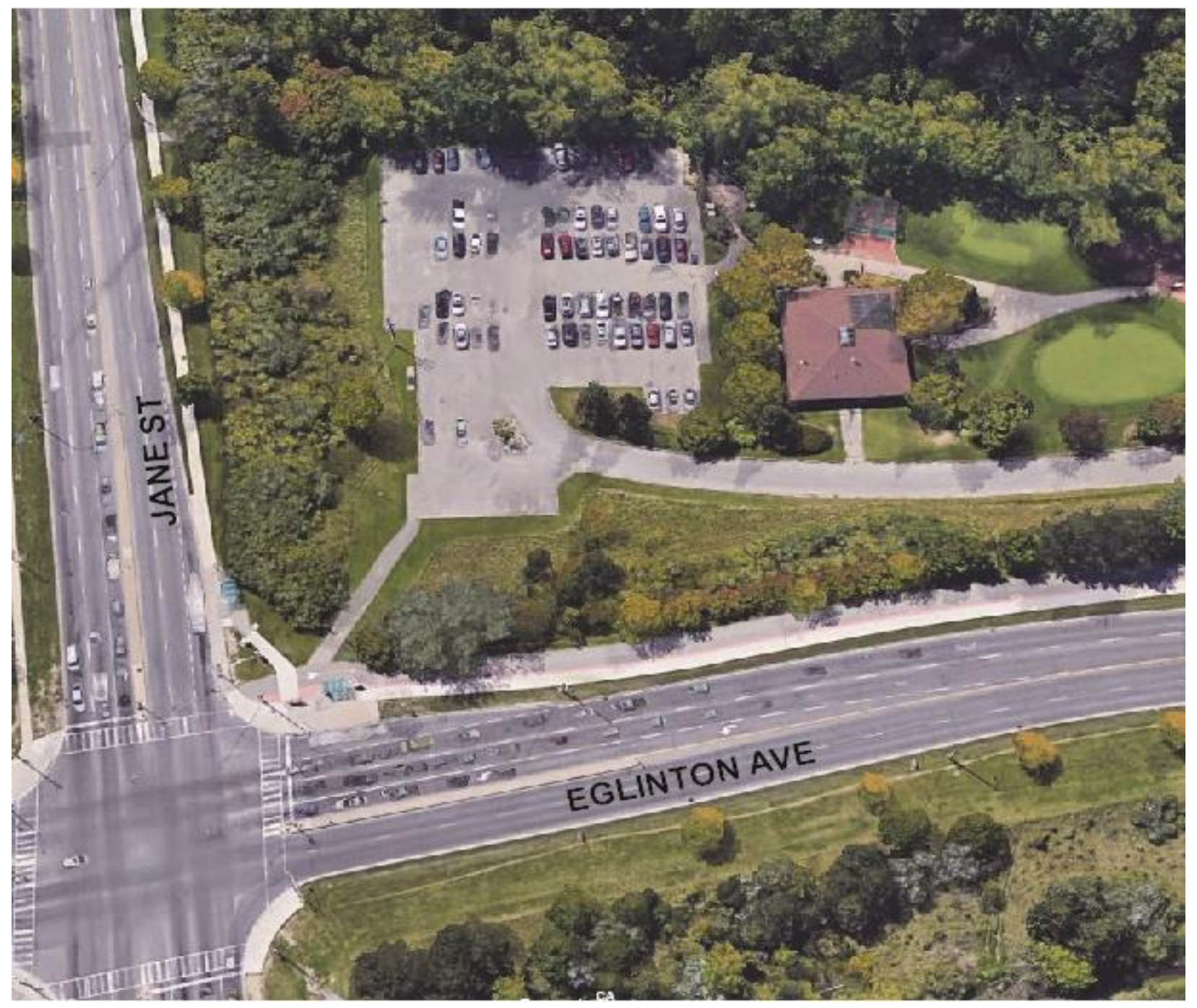

Figure 14: Clubhouse, Parking Lot and Practice Facilities Area at Scarlett Woods. (Google Earth, n.d.)

This parcel is only 1.51 acres in size, yet it has multiple options for redevelopment. On a minor scale, an additional one or two storeys could be added to the clubhouse. The maximum height allowed in an Open Space - Golf Course Zone is 14.0 meters or 4 storeys and the clubhouse is currently only one storey. Hence, an addition of up to three storeys could be built without requiring a re-zoning or Zoning By-law Amendment. 
The parking lot could alternatively be redeveloped and a mixed-use building featuring affordable and market rate rental housing, space for uses such as a daycare or library and belowgrade parking could be constructed. This proposed building would be 24-storeys tall, the same height as many other high-rise apartment buildings in area surrounding Scarlett Woods.

A 24-storey building would provide roughly 275 - 350 units and should focus on providing rental units, specifically affordable rental units. If $30 \%$ of the units were purpose-built, affordable rental, it would create between 82 - 105 units that would help to address one of Toronto's most pressing challenges, the lack of affordable housing. The lower floors of the building would house institutional space or in some scenarios, a new clubhouse. Condominium units could be considered on the site, but if the property were to operate on a public land lease, the condominium option would not be economically feasible to developers. This proposed development would also incorporate some of the best practices of golf course adaptation such as introducing non-peak hour activities on the property. This scenario is also different from the redevelopment scenarios examined in Chapter Three as the golf course is retained and remains operational in this instance. 


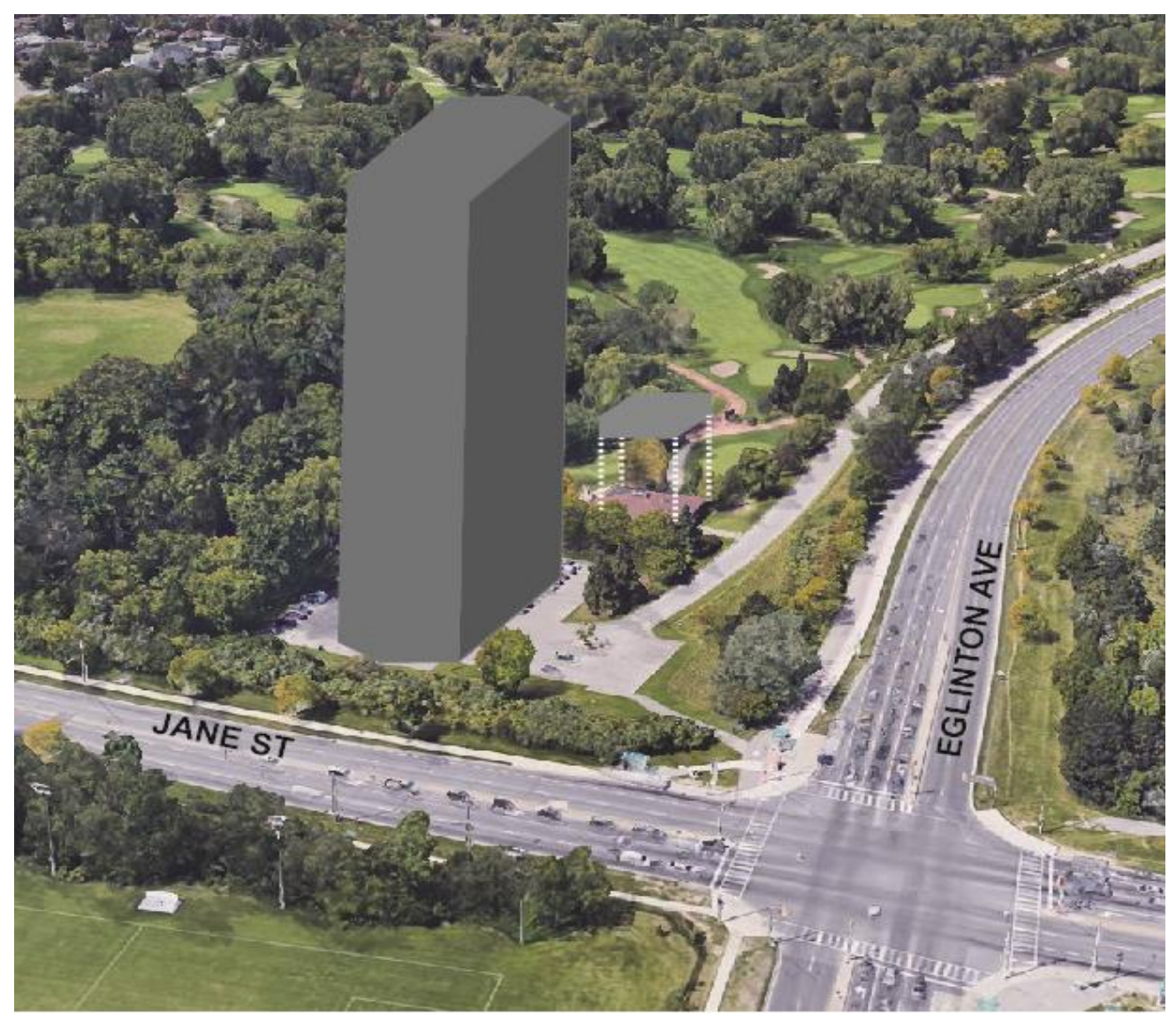

Figure 15: Rendering of Scarlett Woods Clubhouse area featuring Mixed-Use Tower and Possible Clubhouse Addition. (Google Earth, n.d.)

While these redevelopment scenarios are restricted by TRCA regulations and are not as large as redevelopments examined earlier in this paper, they do provide a sense of what redevelopment could resemble on the Scarlett Woods property.

\subsubsection{Recommendations}

All three of the proposed scenarios for adaptation of Scarlett Woods have their strengths and weaknesses but all are feasible options for the property. The best scenario for Scarlett Woods would be either the reuse scenario or the conversion scenario. These options are preferred to the redevelopment option as Scarlett Woods is located in a floodplain and as recent global events such as Hurricane Harvey's flooding in Houston have proven, building in floodplains is not good planning and has damaging long-term effects. 
The reuse scenario is the less intrusive of the two recommended scenarios. The scenario's weakness might be that it does not maximize usage of the land to provide enough public benefit as golf related activities would remain the priority on the property. The urban farm and use of the site as a public park in the offseason do however provide substantial increased public benefit on the property. Additionally, this scenario is not capital intensive and the revenue generated from the urban farm and potentially from temporary uses might reduce Scarlett Woods' financial losses and alleviate the economic concerns regarding the course.

The conversion scenario is also a strong scenario which could be implemented it if the reuse scenario was not deemed successful enough. Retaining nine holes of golf on the property would strike a balance between local golfers and non-golfing residents as each could use the property. The elimination of half the golf course however would likely further increase financial issues for Scarlett Woods as fewer paying customers would be able to play at once.

One large park on the site would remove any concerns about golf course funding, however the Scarlett Woods property is already located next to an abundance of public parkland. The addition of the Scarlett Woods site to the local park system might not bring much additional benefit to the nearby community with the presence of parks already existent. Closing the golf course however, would represent the loss of the last public golf facility in southwestern Toronto making the sport extremely inaccessible to thousands of Torontonians who live in that portion of the city so the negatives of this scenario may outweigh the positives.

It also important to understand the role the public would play in any adaptation of Scarlett Woods. The final decisions regarding the property rest with City staff and local politicians, however the public must be consulted on any major changes occurring to the property. Public 
notices similar to those seen at proposed development sites should be posted and inform the public of what changes will be occurring at Scarlett Woods. There should also be a series of surveys distributed to both golfers at Scarlett Woods and local residents to gather information on proposed adaptations of the property. These surveys should be made available both online and via mail and should be distributed beyond the Rockcliffe-Smythe neighbourhood given that Scarlett Woods serves many of the neighbourhoods in southwestern Toronto.

A series of public open houses should also be held giving residents the opportunity to present ideas beyond the ones discussed in this paper. This feedback, along with the information gathered from the surveys would be used to help shape the site-specific policies crafted by City staff. The policy could then undergo public consultation with another round of open houses, additional surveys and possible testing of the additional uses on site for short periods of time. From this public engagement, the preferred options would be identified, and any adaptation of Scarlett Woods should proceed including those options. By performing this type of lengthy public consultation, it would ensure the public was involved in the process and had its needs represented in the adaptation of the golf course. 


\subsection{Dentonia Park Golf Course Context}

The second case study in this chapter will be on Dentonia Park Golf Course. Dentonia Park is located in the Toronto borough of Scarborough near the corner of Victoria Park Avenue and Danforth Avenue. The golf course is an 18-hole, par 55 measuring 2176 yards in distance with all holes on the course being par 3's (City of Toronto , n.d.).

Similar in style to Scarlett Woods, Dentonia Park's short length and lack of long and challenging holes has made it popular with beginners and juniors. The course is also easily accessible by public transit, located directly beside Victoria Park subway station and is the most affordable of all City of Toronto golf courses with green fees ranging from $\$ 27$ - \$29.50 (City of Toronto , n.d.). These prices make Dentonia Park one of the most affordable golf courses in all of the GTA. Dentonia Park also has a clubhouse equipped with a washroom and a pro shop, practice facilities and a 55-space parking lot (City of Toronto , n.d.). It is important to note however that Dentonia Park's clubhouse is much smaller than Scarlett Woods' and does not feature a restaurant.

Dentonia Park has struggled the most of the five municipal courses in Toronto recently. 31,407 rounds were played at Dentonia Park in 2005 but that figure had dropped to 24,343 by 2015 , representing a decline of $22.5 \%$ (Cain, 2016). The course also lost $\$ 822,000$ from 20072011, the largest amount lost by any of the five municipal courses (some courses actually posted profits during this period) (Cain, 2016). 


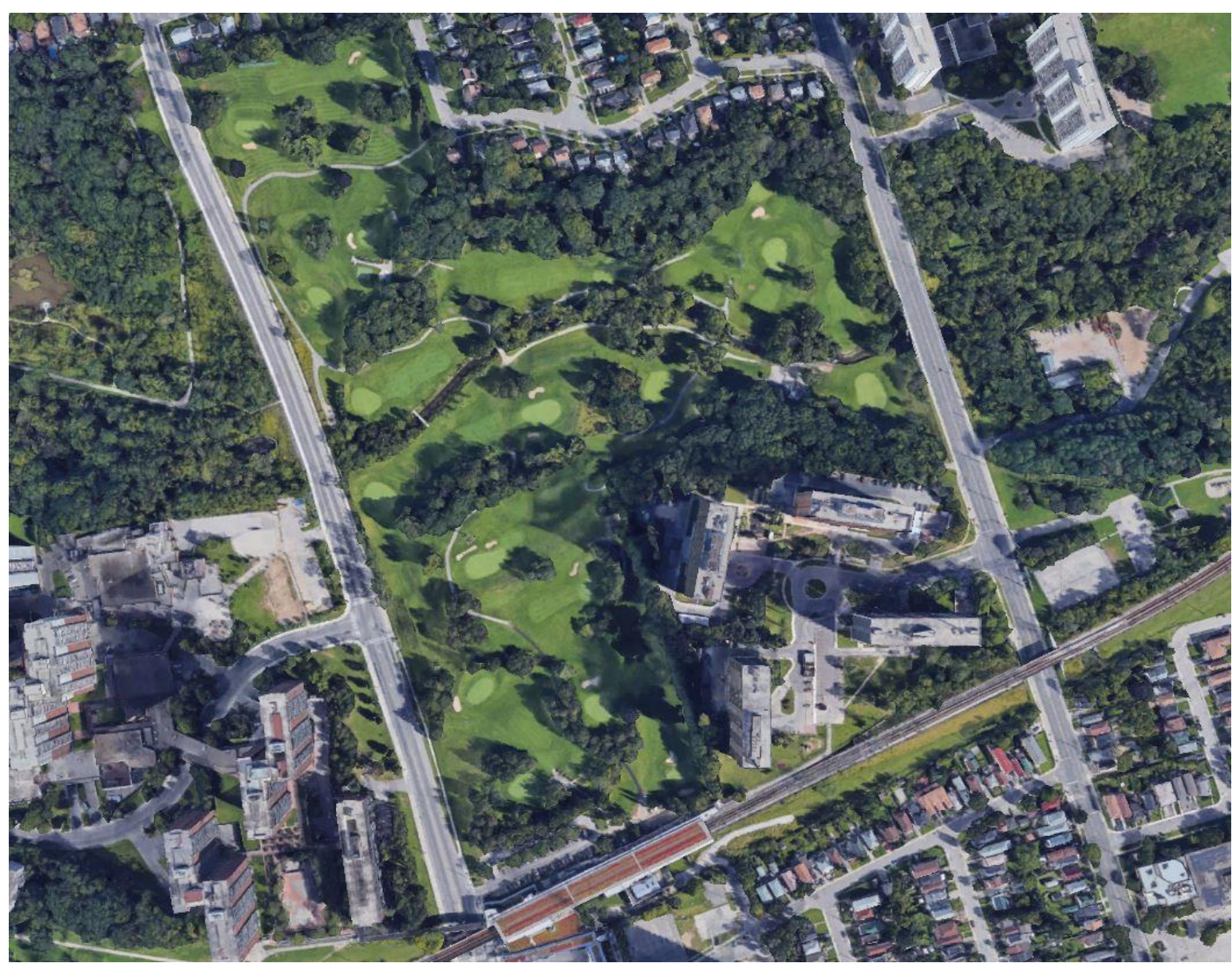

Figure 16: Aerial View of Dentonia Park Golf Course. (Google Earth, n.d.)

\subsubsection{Site Context}

The Dentonia Park property is roughly 36.7 acres in size and is part of the Oakridge neighbourhood according to the Toronto Neighbourhood Profiles. Dentonia Park is also heavily associated with the Crescent Town neighbourhood which borders on the Oakridge neighbourhood to the west. The golf course is bordered by a low-density residential neighbourhood to the north, the Warden Woods Off-Leash Dog Park and several high-rise apartment buildings to the east, TTC Line 2 and Victoria Park Station to the south and Taylor Creek Park to the west.

The Oakridge neighbourhood is home to roughly 13,000 people and is amongst the least affluent parts of Toronto. The Median Household Income in Oakridge measures roughly \$26,000 
less than the Toronto average and several poverty indicators such as percentage of income from government transfers measure much higher than the citywide average (City of Toronto Social Policy, Analysis \& Research, 2018). Oakridge is also unique in the sense that it is home to a high proportion of recent immigrants. $12.9 \%$ of Oakridge residents are recent immigrants compared to the 7.0\% citywide average in Toronto (City of Toronto Social Policy, Analysis \& Research, 2018). The percentage of visible minorities is also higher in Oakridge then the rest of Toronto by $23.8 \%$ (City of Toronto Social Policy, Analysis \& Research, 2018).

Like the Rockcliffe-Smythe neighbourhood where Scarlett Woods is located, Oakridge has been identified as a Neighbourhood Improvement Area in the TSNS 2020 (City of Toronto, n.d. ). An action plan for the Taylor-Massey Oakridge neighbourhood has been established and is aiming to improve the neighbourhood through a variety of programs that will activate people, policy and resources (City of Toronto Social Development, Finance \& Administration, 2019).

The physical character of the neighbourhood is defined by a number of large high-rise apartments and the Warden Woods, a large wooded ravine. Retail is present in the neighbourhood along Danforth Avenue and Warden Avenue with low-density residential neighbourhoods forming the remainder of the neighbourhood. Single-family homes however are not the most popular form of housing in Oakridge with $68.2 \%$ of households identifying as renters, much higher than the Toronto average of 47.2\% (City of Toronto Social Policy, Analysis \& Research, 2018).

\subsubsection{Planning Context}

In Toronto's Official Plan, Dentonia Park has a land use designation of Other Open Space Areas (Including Golf Courses, Cemeteries, Public Utilities). Lands with this designation are to be used primarily for golf courses, cemeteries, and open spaces associated with utilities and other specialized uses and facilities. The Official Plan generally prohibits development in Parks and 
Open Space Areas with the exceptions of recreational and cultural facilities, conservation projects, cemetery facilities, public transit and essential public works and utilities where supported by appropriate assessment. The Official Plan also establishes the criteria for development in Parks and Open Space Areas and the criteria for development can be found in detail in Appendix A.

The City of Toronto Zoning By-law 569-2013 zones Dentonia Park as Open Space - Golf Course. Open Space - Golf Course Zone, like the Official Plan, is very restrictive of what is permitted. The complete list of permitted uses and permitted uses with conditions pertaining to Open Space - Golf Course Zones can be found in Appendix B, however some of the important permitted and conditionally permitted uses for OG zoned lands are parks, club, eating establishment, educational use and personal service shop. The maximum height for the property is $14.0 \mathrm{~m}$ or 4 storeys and it is also not subject to any Secondary Plans or site-specific policies.

Dentonia Park is situated in TRCA regulated lands and TRCA designated floodplain lands however unlike Scarlett Woods, these designations do not apply to the entire property. Only roughly 23.41 acres of the property are TRCA regulated land and even less of the property is designated floodplain lands. Figures 17 and 18 illustrate which segments of the land are TRCA regulated and TRCA designated floodplain lands. $100 \%$ of the designated floodplain lands are with the TRCA regulated lands meaning that a total of $33.7 \%$ of the property is free of any TRCA restrictions. 


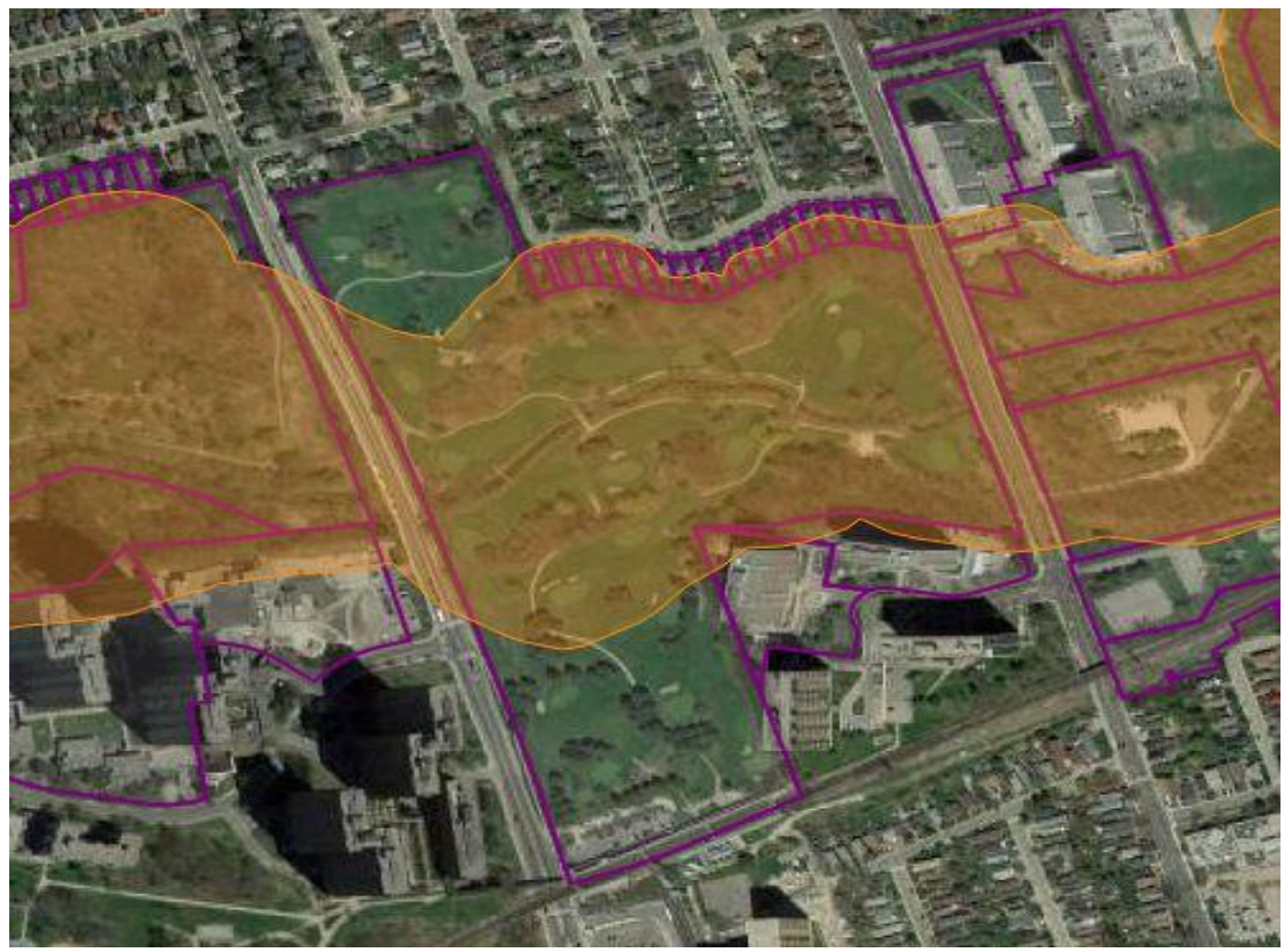

Figure 17: TRCA Regulated Lands at Dentonia Park Golf Course. Regulated lands are shown in orange. (TRCA, 2019)

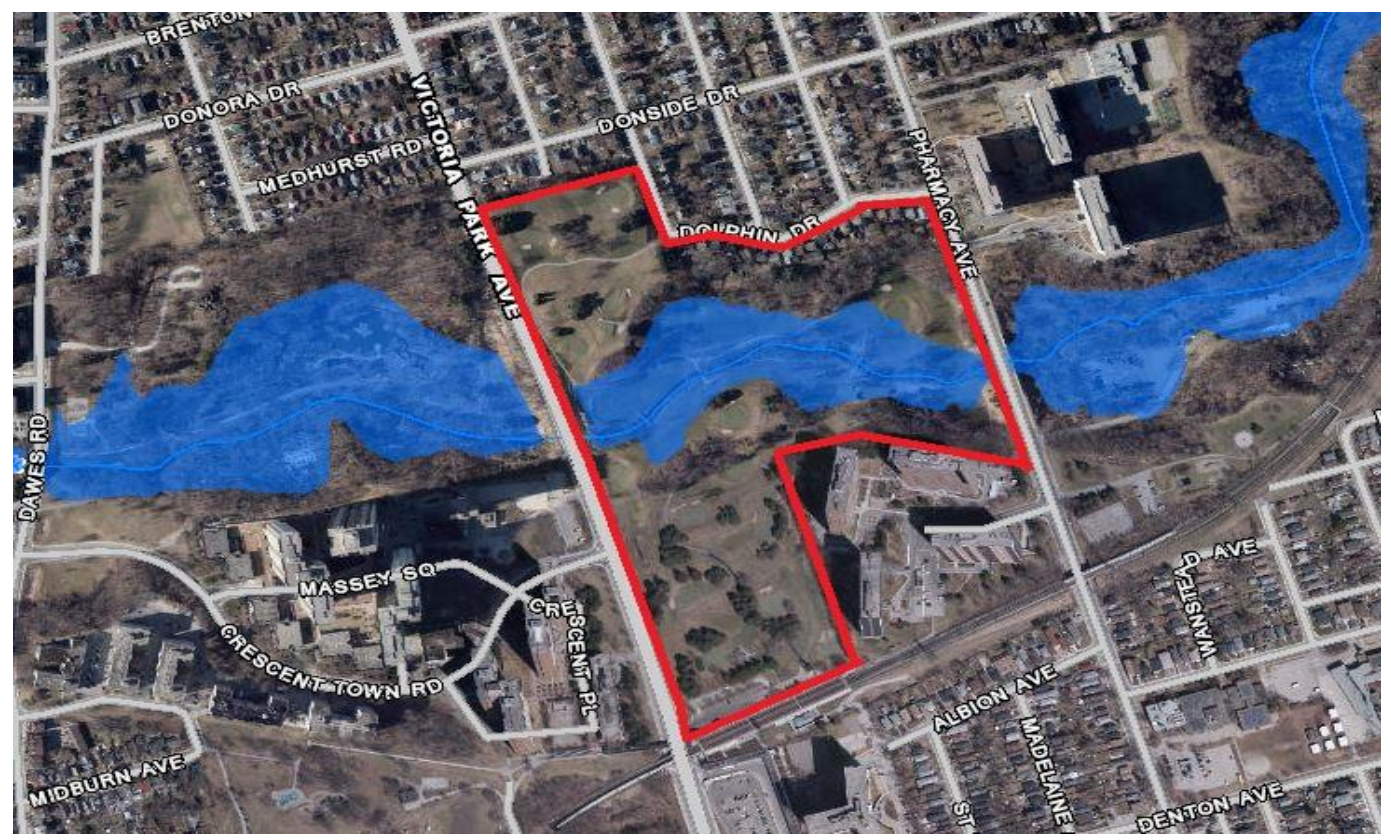

Figure 18: TRCA Designated Floodplain Lands at Dentonia Park Golf Course. The floodplain lands are shown in blue while the golf course property is outlined in red. (TRCA, 2018) 


\subsubsection{Reuse Scenario}

The first proposed scenario of adaptation at Dentonia Park will be the reuse scenario. Keeping the golf course operational at Dentonia Park is a strong option given the floodplain designation on part of the property. Resembling the Scarlett Woods reuse scenario, alternative forms of golf should be encouraged on the property and the golf course should be opened as a park during the offseason with the potential to allow winter activities such as cross-country skiing on site.

An urban farm would also be a good addition to the property however, Dentonia Park has very little excess land that is not part of the golf course so multiple holes would have to be sacrificed in order to construct an urban farm. This will not be explored in this scenario since keeping the golf course intact is a priority of reuse scenarios. Pop-up parks and temporary uses could also be introduced at Dentonia Park year-round.

This reuse scenario incorporates many of the best practices of golf course adaptation such as increasing public benefit and permitting offseason activities, yet it is not as attractive as the Scarlett Woods reuse scenario due to the lack of an urban farm and the overall small size of the clubhouse and property which could limit what temporary uses can occur on the property.

\subsubsection{Conversion Scenario}

The second option that will be explored is the conversion of Dentonia Park to a public park. Like Scarlett Woods, this can be done in one of two ways. The first option would involve retaining

holes $1-5,16,17 \& 18$ of the current golf course and creating a new $6^{\text {th }}$ hole from the existing $14^{\text {th }}$ hole tee box and $13^{\text {th }}$ hole green to create a 9-hole golf course. This new course would be entirely on the portion of the property south of Massey Creek allowing the northern portion of the property to become a public park. The new routing of the golf course is logical as it begins and ends near 
the clubhouse and the clubhouse and parking lot could remain in their current locations and continue to serve golf course portion of the property. Figure 19 illustrates what this might look like.

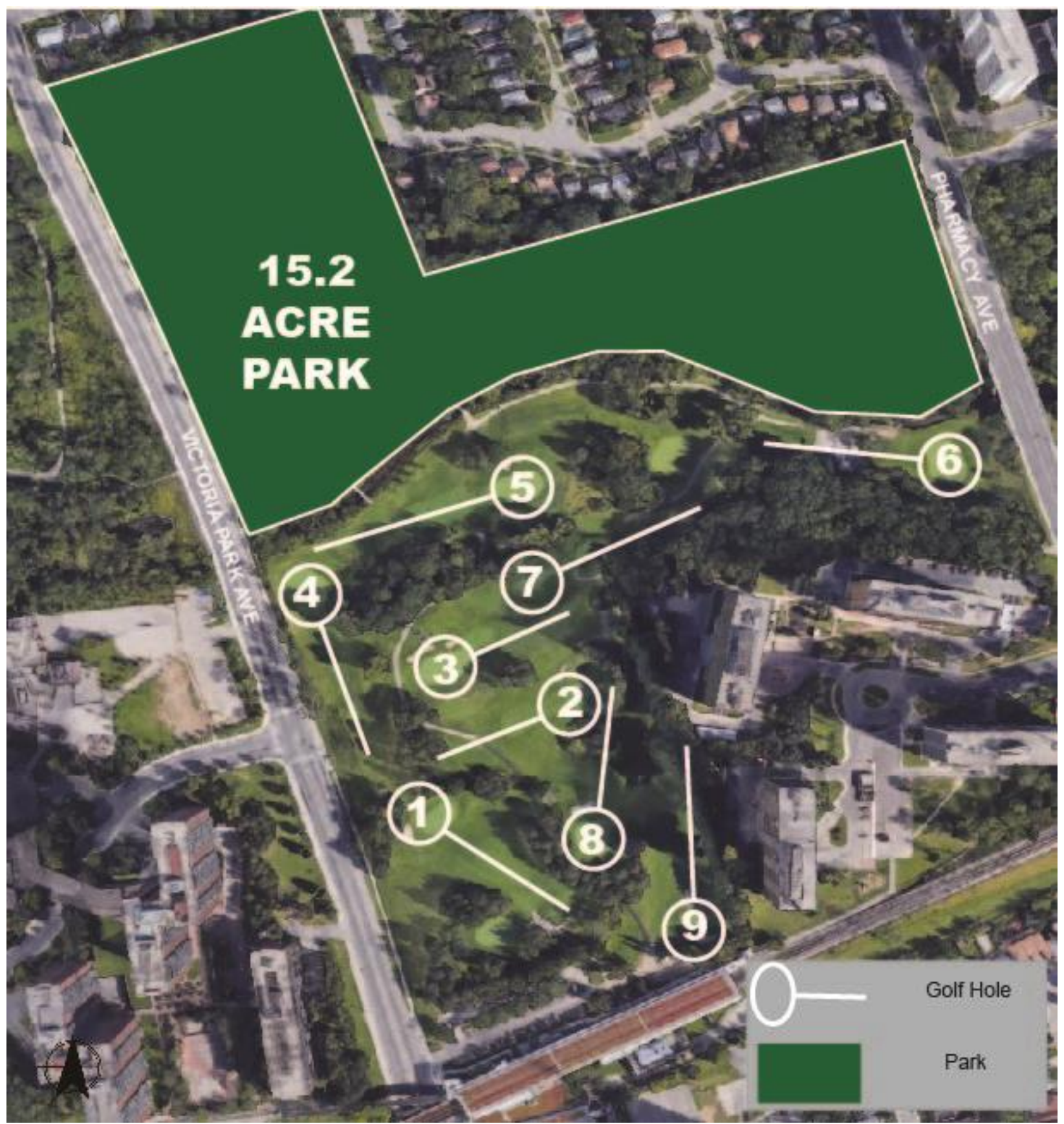

Figure 19: Proposed Conversion of Dentonia Park to a Public Park and 9-hole Golf Course. (Google Earth, n.d.) 
The northern side of Massey Creek would become a 15.2-acre park with the creek serving as a natural boundary between the park and golf course. The creation of a park would allow it to seamlessly connect to the public parks on either side of property by underpasses beneath Victoria Park Ave and Pharmacy Ave. This would also allow the Gus Harris Trail, a 3-kilometer nature trail which ends at the eastern border of Dentonia Park to be connected to the Taylor Creek Trail which begins on the western side of the Dentonia Park property. Currently, Dentonia Park prevents these trails from connecting but a continuous trail would be possible if a portion of the Dentonia Park property were converted to a park. Figure 20 depicts what this continuous trail system would look like.

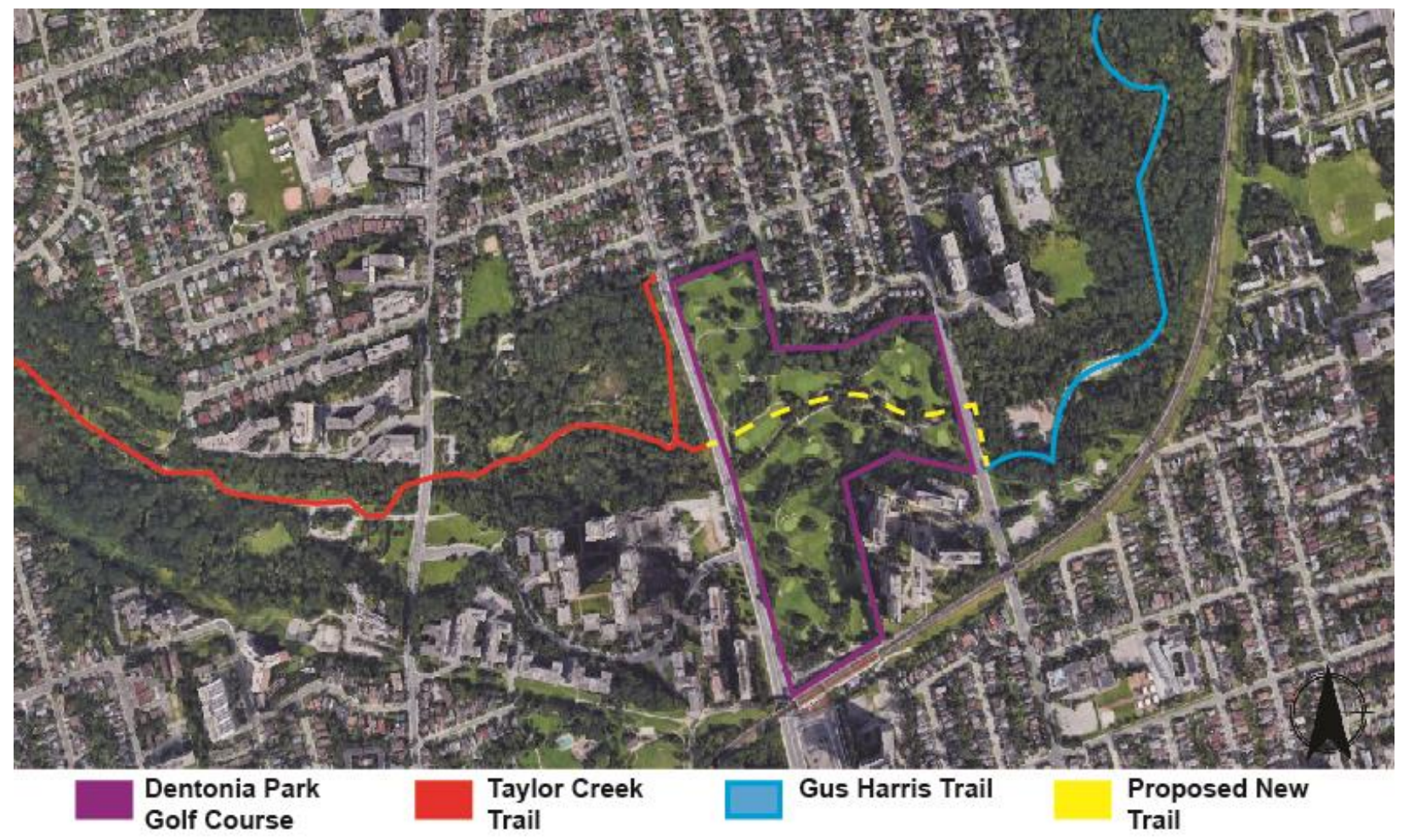

Figure 20: Map of Nature Trails Near Dentonia Park. Conversion of the northern half of the golf course to a park would allow for the proposed trail in yellow to be constructed linking the Gus Harris Trail and the Taylor Creek Trail. (Google Earth, n.d.) 
The second option for park conversion would see the entire property converted to a 35.3acre park. This would again allow for the connected nature trail, but all golf operations would disappear from the property. In either scenario, a rezoning of the park section of the property would be required. Overall, the conversion scenario incorporates many of the best practices of golf course adaptation and may be the best option for Dentonia Park given its finances, location in TRCA regulated land and nearby residents who mostly reside in apartment units that do not have private yards.

\subsubsection{Redevelopment Scenario}

The final scenario that will be examined in this chapter is a redevelopment scenario. Compared to Scarlett Woods, redevelopment is a much more likely scenario at Dentonia Park as only part of the property is TRCA regulated land. Dentonia Park is also a more attractive site for development being located beside an existing subway station and near the shops and amenities of Danforth Village.

Massey Creek runs through the middle of the property and the lands surrounding the creek are TRCA regulated presenting challenges to development on the site. TRCA regulated land comprises roughly $66.3 \%$ of the property leaving two parcels of land that are unregulated. The northern parcel is roughly 7.3 acres in size while the southern parcel is only roughly 3.9 acres. Figure 14 shows these two parcels and the TRCA regulated lands. It is important to once again note that development is not prohibited on TRCA regulated land but that a permit is required, and permits are granted on a site-by-site case. 


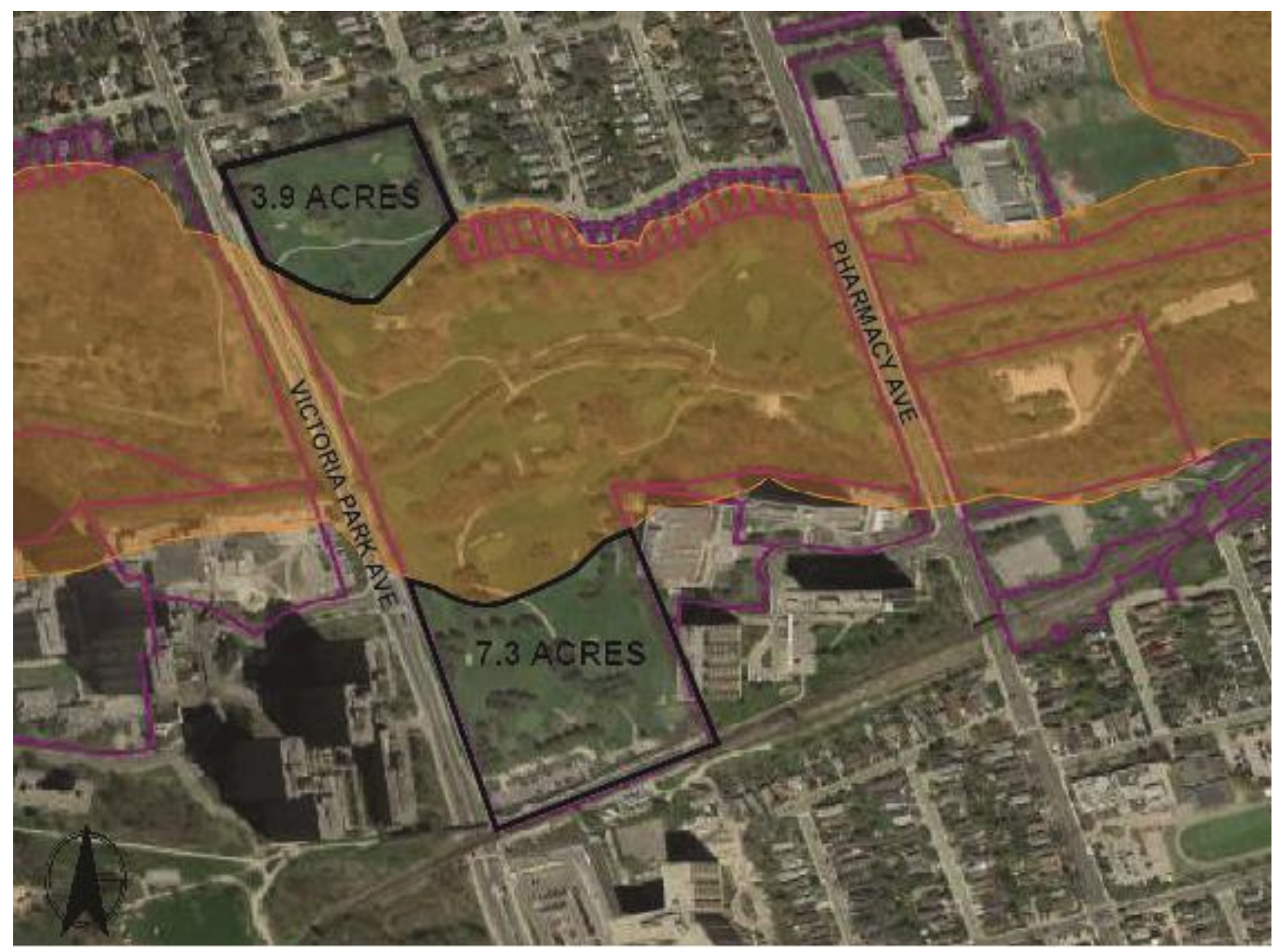

Figure 21: Map Depicting Both Developable Parcels at Dentonia Park. TRCA regulated lands are shown in orange. (TRCA, 2019)

A potential development scenario at Dentonia Park could include three mixed-use buildings with two on the southern parcel of developable land and one on the northern portion. Each of these three buildings could contain affordable housing, market housing as well as community space and retail on the lower levels. In keeping with the neighbourhood character, the buildings should be between 20-30 storeys in height and would each contain between 500 - 550 residential units of varying sizes to accommodate a wide range of family structures. Most of the nearby buildings in Crescent Town are rental apartments and given the need for affordable rental units in Toronto currently, purpose-built rental should be the focus of the proposed buildings. If 
$30 \%$ of the units in each building were dedicated to being affordable units, the entire site could provide an affordable housing supply of between $450-495$ units.

The community space segment of the buildings would be in the podiums and could provide a permanent home for the groups and services identified in the Taylor - Massey Oakridge Neighbourhood Action Partnership such as Green Sprouts, which provides financial literacy training for youth or Women's Worth, which provides language and computer training for women (City of Toronto Social Development, Finance \& Administration , 2019). Additional services such as a daycare could also be considered on the site and could occupy space on the lower levels of the buildings.

The remainder of the property that is TRCA regulated would serve as park. Unlike the neighbouring parks which are wooded natural areas, this new park could contain playing fields, playgrounds and other park features that would differentiate it from the surrounding parks. The continuous nature trail that was shown in Figure 20 would also be possible in this scenario. This scenario would require an Official Plan Amendment, a subdivision of the site and a rezoning of the entire property to account for its new land-uses. It is also recommended that the entire property be retained by the City and a public land leasing system be implemented. Using a public land lease would provide the City with greater control over the development of the property and the opportunity to collect annual ground rent from the site which could be used to fund the proposed public services. 


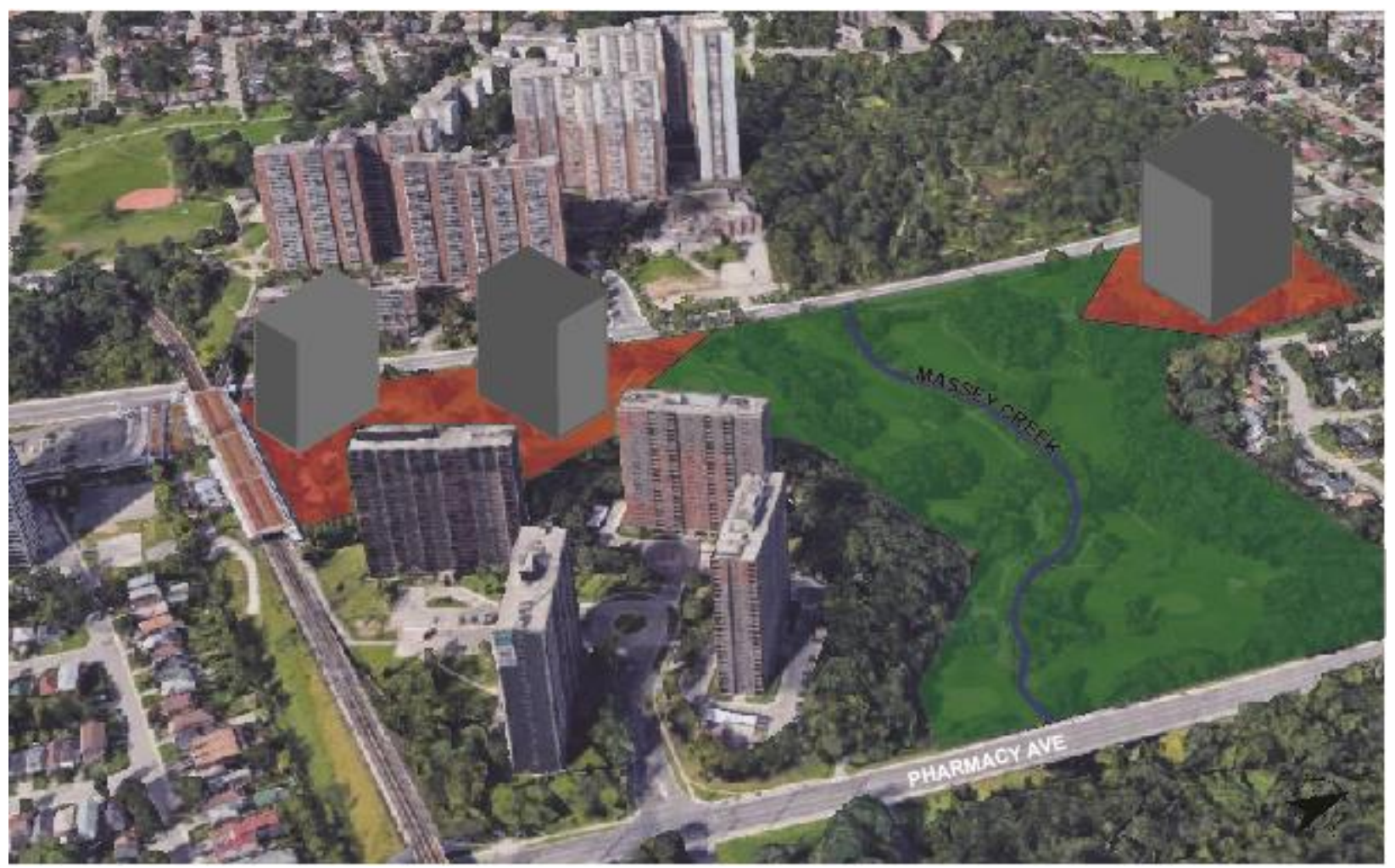

Figure 22: Rendering of Potential Development at Dentonia Park. The red portions of land are developable while the green lands comprising the middle of the site would form a new public park. (Google Earth, n.d.)

\subsubsection{Recommendations}

All three scenarios shown in this chapter utilize the best practices of golf course adaptation and could each be implemented at Dentonia Park. The redevelopment scenario in this instance is the best choice for Dentonia Park given its mounting financial losses and redevelopment opportunities. Dentonia Park is the only City of Toronto municipal golf course that has developable sized portions of land that are not TRCA regulated and the course is also the worst financial performer of the five Toronto municipal courses. Dentonia Park also does not best serve the needs of its neighbourhood residents who lack the disposable income to golf. Redeveloping the site to include community space and new affordable housing would better benefit those living near the golf course. 
The reuse scenario at Dentonia Park was not chosen as it is much weaker than at Scarlett Woods due to the lack of an urban farm. While opening the course as a park during the offseason would benefit local residents, this could be accomplished on a more permanent basis by converting half or all the property into a public park. Of the two conversion scenarios, keeping 9-holes might again provide an ideal compromise between golfers and non-golfers. Both the 9-hole and complete conversion scenarios in this case would allow for the continuous nature trail to be created, an important piece of good planning for the Oakridge neighbourhood and Scarborough.

The same public consultation process that was detailed in the Scarlett Woods recommendations should again be followed for Dentonia Park. By collaborating with local residents, City staff will be able to ensure that the best interests of the public are represent in an adaptation of the golf course. The negative effect of closing Dentonia Park would be the removal of the only municipal golf course in the south-central part of the city. Unlike the Scarlett Woods case however, Flemington Park Golf Club, a privately-owned, public golf course with affordable green fees in the same range as Dentonia Park is located only $6.2 \mathrm{~km}$ away. While having another golf course in such close proximity may have contributed to Dentonia Park's financial woes, the presence of Flemington Park means that golfers in East York and southern Scarborough will not be left without a public golf course. 


\subsection{Conclusions and Final Recommendations}

The dilemma of financially troubled municipal golf courses is not easy for cities to solve. While declining participation rates in golf and a lack of revenues may make closing courses an obvious solution, the problem is far more complex. Golf is on the decline, yet it is important to realize that the sport is not dead and is still enjoyed by thousands of Toronto area residents. Participation numbers may increase in near future as the baby boomer generation enters retirement causing distinct changes to the economy. Golf is particularly popular amongst seniors and the aging population may renew demand for municipal golf courses.

It is also important to consider that most municipal recreation facilities such as arenas or recreation centres do not generate revenue and receive funding from tax dollars. These facilities are not penalised for their failure to generate revenue as it is accepted that they provide public benefit and are required to contribute to creating a diverse and wide-range of recreational opportunities. Golf courses should be regarded no differently than these facilities as they help contribute to the urban fabric of cities.

While it is important to recognize the benefits of municipal golf courses, the challenges of cities must also be addressed. Cities like Toronto face a number of issues and the time has now arrived where municipal facilities can no longer remain empty for half the year. From the two case studies observed in Chapter 6, it is clear municipalities such as Toronto have multiple options for adapting their City-owned golf courses. These adaptations vary in magnitude and can be as small as adding temporary uses on the golf property or as large as a complete redevelopment. By using the best practices identified in this paper, municipalities can choose the scenario that will fit their unique situation and then make the choices that will allow for the best utilization of their municipal golf courses. Most importantly however, the public must be 
properly consulted on any adaptation given that municipal golf courses are public lands who's first and foremost use must be serving the public. 


\section{APPENDIX A}

\section{City of Toronto Official Plan}

Land Use Designation: Other Open Spaces Areas (Golf Courses, Cemeteries, Public Utilities)

Official Plan Policy

1. Parks and Open Space Areas are the parks and open spaces, valleys, watercourses and ravines, portions of the waterfront, golf courses and cemeteries that comprise a green open space network in Toronto. They comprise the areas shown on Maps 13-23 shown as Natural Areas, Parks and Other Open Space Areas.

2. Development is generally prohibited within Parks and Open Space Areas except for recreational and cultural facilities, conservation projects, cemetery facilities, public transit and essential public works and utilities where supported by appropriate assessment. Hydro uses will have primacy of use on those lands identified as hydro corridors on Maps 13-23.

3. The areas shown as Natural Areas on Maps 13-23 will be maintained primarily in a natural state, while allowing for:

a. compatible recreational, cultural and educational uses and facilities that minimize adverse impacts on natural features and functions; and

b. conservation projects, public transit, public works and utilities for which no reasonable alternatives are available, and that are designed to have only minimal adverse impacts on natural features and functions.

4. The areas shown as Parks on Maps 13-23 will be used primarily to provide public parks and recreational opportunities.

5. The areas shown as Other Open Space Areas on Maps 13-23 will be used primarily for golf courses, cemeteries, and open spaces associated with utilities and other specialized uses and facilities.

Official Plan Development Criteria

6. Any development provided for in Parks and Open Space Areas will:

a. protect, enhance or restore trees, vegetation and other natural heritage features;

b. preserve or improve public visibility and access, except where access will damage sensitive natural heritage features or areas, or unreasonably restrict private property rights; 
c. maintain, and where possible create linkages between parks and open spaces to create continuous recreational corridors;

d. maintain or expand the size and improve the usability of publicly owned Parks and Open Space Areas for public parks, recreational and cultural purposes;

e. respect the physical form, design, character and function of Parks and Open Space Areas; and

f. provide comfortable and safe pedestrian conditions.

7. Parks and Open Space Areas that are privately owned are not necessarily open to the general public nor intended to be purchased by the City. If an application is made to develop such lands and the City or a public agency does not wish to purchase them to extend the public open space system, the application will be considered on the basis of its consistency with the policies of this Plan.

8. The sale or disposal of publicly owned lands in Parks and Open Space Areas is discouraged and no City owned lands in Parks and Open Space Areas will be sold or disposed of. However, City owned land in Parks and Open Space Areas may be exchanged for other nearby land of equivalent or larger area and comparable or superior green space utility. 


\section{APPENDIX B}

\section{City of Toronto Zoning By-law 2013-569}

Zoning Type: Open Space Golf Course

Zoning Label: OG

\section{Chapter 90 Open Space}

90.40 Open Space - Golf Course Zone (OG)

90.40.1 General

90.40.1.10 Interpretation

(1) Application of this Section

The regulations in Section 90.40 apply to all lands, uses, buildings and structures in the OG zone.

Permitted Use:

90.40.20.10 Permitted Use

(1) Use - OG Zone

The following uses are permitted in the OG zone:

- Ambulance Depot

- Golf Course

- Fire Hall

- Park

- Police Station

- Public Utility

- Transportation Use

Permitted Use - with Conditions:

90.40.20.20 Permitted Use - with Conditions

(1) Use with Conditions - OG Zone

The following uses are permitted in the OG zone, if they comply with the specific conditions associated with the reference number(s) for each use in Clause 90.40.20.100:

- Amusement Arcade (1)

- $\quad$ Club (2)

- Cogeneration Energy (3)

- Eating Establishment (2)

- Education Use (2)

- Outdoor Patio (4) 
- Personal Service Shop (5)

- Place of Assembly (2)

- Recreation Use (2)

- Renewable Energy (3)

- Retail Store (5)

- Service Shop (5)

- Take-out Eating Establishment (5)

90.40.20.100 Conditions

(1) Amusement Arcade

In the OG zone, an amusement arcade:

(A) must be combined with a park or a golf course; and

(B) may have no more than 12 amusement devices.

(2) Club, Eating Establishment, Education Use, Place of Assembly, or Recreation Use

In the OG zone, a club, an eating establishment, an education use, a place of assembly, or a recreation use must be combined with a park or a golf course.

(3) Cogeneration Energy Production or Renewable Energy Production

In the OG zone, cogeneration energy production or renewable energy production must be in combination with another permitted use on the lot, and comply with all Municipal, Provincial and Federal by-laws, statutes and regulations.

(4) Outdoor Patio

An outdoor patio in the OG zone:

(A) may be no closer than 10.0 metres from a lot in the Residential Zone category or the Residential Apartment Zone category;

(B) despite (A) above, if the outdoor patio is above the first storey of the building, it may be no closer than 40.0 metres, measured horizontally, from a lot in the Residential Zone category or the Residential Apartment Zone category; and

(C) if a lawfully existing outdoor patio is closer to a lot than required in (A) or (B) above, that lawful distance from a lot in the Residential Zone category or Residential 
Apartment Zone category is the minimum distance for that lawfully existing outdoor patio from that lot.

(5) Personal Service Shop, Retail Store, Service Shop, or Take-out Eating Establishment

In the OG zone, a personal service shop, a retail store, a service shop, or a take-out eating establishment:

(A) must be combined with a park or a golf course; and

(B) the interior floor area may no greater than 500 square metres.

90.40.40 Principal Building Requirements

90.40.40.10 Height

(1) Maximum Height

The permitted maximum height for a building or structure on a lot in the OG zone is:

(A) the numerical value, in metres, following the letters "HT" on the Height Overlay Map; or

(B) if the lot is in an area with no numerical value following the letters "HT" on the Height Overlay Map, 15.0 metres.

90.40.40.40 Floor Area

(1) Floor Space Index

In the OG zone, the permitted maximum floor space index is 0.15 .

90.40.40.70 Setbacks

(1) Building Setbacks

In the OG zone, the required minimum building setback from a front lot line, rear lot line and side lot line is the greater of:

(A) 7.5 metres; or

(B) a distance equal to the height of the building or structure. 


\section{Chapter 90 Open Space}

90.5 Regulations Applying to the Open Space Zone Category

90.5.1 General

90.5.1.10 Interpretation

(1) Application of General Regulations Section

The regulations in Section 90.5 apply to all lands, uses, buildings and structures in the Open Space Zone category.

(2) Interpretation of the Open Space Zone Symbol

The zone symbol on the Zoning By-law Map for zones in the Open Space Zone category consists of the letters $\mathrm{O}, \mathrm{ON}, \mathrm{OR}, \mathrm{OG}, \mathrm{OM}$ or $\mathrm{OC}$, indicating the primary land use permitted in the respective zone.

90.5.20 Permitted Uses

90.5.20.1 General

(1) Lawfully Existing Public School, Private School

A lawfully existing public school or private school on a lot in the Open Space Zone category is permitted on that lot, and:

(A) any expansion or addition to the lawfully existing public school or private school building must comply with Section 150.48 and the requirements for the zone in which the lot is located; and

(B) the lawfully existing public school or private school may be replaced with a new school building that complies with Section 150.48 and the requirements for the zone in which the lot is located.

90.5.40 Principal Building Requirements

90.5.40.1 General

(1) Building Requirements 
Additional building requirements are in each zone in the Open Space Zone category.

90.5.40.10 Height

(1) Determining the Height of Buildings or Structures

In the Open Space Zone category, the height of a building or structure is the distance between average grade and the elevation of the highest point of that building or structure.

(2) Height of Specific Structures on a Building

In the Open Space Zone category, the following structures on the roof of a building may exceed the permitted maximum height for that building by:

(A) 1.5 metres for:

(i) parapets for a green roof; and

(ii) weather vanes; or

(B) 5.0 metres for:

(i) antennae;

(ii) flagpoles; and

(iii) satellite dishes.

(3) Height of Elements for Functional Operation of a Building

In the Open Space Zone category, the following equipment and structures on the roof of a building may exceed the permitted maximum height for that building by 5.0 metres, subject to regulation 90.5.40.10(4):

(A) equipment used for the functional operation of the building, such as electrical, utility, mechanical and ventilation equipment;

(B) structures or parts of the building used for the functional operation of the building, such as enclosed stairwells, roof access, maintenance equipment storage, elevator shafts, chimneys, vents, and water supply facilities; and 
(C) structures that enclose, screen or cover the elements listed in (A) and (B) above.

(4) Height - Horizontal Limits on Elements for Functional Operation of a Building In the Open Space Zone category, equipment, structures or parts of a building that exceed the permitted maximum height for a building in regulation 90.5.40.10(3), must comply with the following:

(A) their total area may cover no more than $30 \%$ of the area of the roof, measured horizontally; and

(B) if located within 6.0 metres of a lot line abutting a street, their total horizontal dimension, measured parallel to the street, may not exceed $20 \%$ of the width of the building's main walls facing that street.

(5) Height of Rooftop Amenity Space Safety and Wind Protection

In the Open Space Zone category, unenclosed structures providing safety or wind protection to rooftop amenity space may exceed the permitted maximum height for that building by 3.0 metres, if the structures are no closer than 2.0 metres from the interior face of any main wall.

\subsubsection{Height Exemptions}

(1) Permitted Height for Lawfully Existing Buildings

In the Open Space Zone category, if the lawful height of a lawfully existing building or structure is greater than the permitted maximum height for a building or structure, that lawful height is the permitted maximum height for that lawfully existing building or structure.

(2) Additions to Lawfully Existing Buildings

Any addition or extension to a lawfully existing building or structure referred to in regulation 90.5.40.11(1) must comply with the permitted maximum height for a building or be authorized by a Section 45 Planning Act minor variance.

(3) Alterations to the Roof of Lawfully Existing Buildings 
Any alteration to the roof of a lawfully existing building referred to in regulation 90.5.40.11(1) may be constructed to the permitted maximum height in regulation 90.5.40.11(1).

\subsubsection{Floor Area}

\section{(1) Floor Space Index Calculation}

In the Open Space Zone category, the floor space index is the result of the gross floor area of a building divided by the area of the lot.

\subsubsection{Floor Area Exemptions}

(1) Permitted Gross Floor Area for Lawfully Existing Buildings

In the Open Space Zone category, if the lawful gross floor area of lawfully existing buildings on a lot is greater than the permitted maximum gross floor area, the lawful gross floor area of those lawfully existing buildings is the permitted maximum gross floor area for those lawfully existing buildings on that lot.

(2) Permitted Floor Space Index for Lawfully Existing Buildings

In the Open Space Zone category, if the lawful gross floor area of lawfully existing buildings on a lot results in a floor space index greater than the permitted maximum floor space index, the lawful floor space index of those lawfully existing buildings is the permitted maximum floor space index for those lawfully existing buildings on that lot.

\subsubsection{Permitted Encroachments}

\section{(1) Canopies and Awnings}

In the Open Space Zone category, a canopy, awning or similar structure, with or without structural support, may encroach into a required minimum building setback that abuts a street, if no part of the canopy, awning or similar structure is located more than 5.0 metres above the elevation of the ground directly below it.

90.5.40.70 Setbacks

(1) Building or Structure to be Set Back from a Lane 
A building or structure in the Open Space Zone category may be no closer than 2.5 metres from the original centreline of a lane.

\subsubsection{Setbacks Exemptions}

(1) Permitted Setbacks for Lawfully Existing Buildings

In the Open Space Zone category, if the lawful building setback of a lawfully existing building or structure is less than the required minimum building setback from:

(A) a front lot line, that lawful building setback is the required minimum front yard setback for that lawfully existing building or structure;

(B) a rear lot line, that lawful building setback is the required minimum rear yard setback for that lawfully existing building or structure; and

(C) a side lot line, that lawful building setback is the required minimum side yard setback for that lawfully existing building or structure.

(2) Additions to Lawfully Existing Buildings

Any addition or extension to a lawfully existing building or structure referred to in regulation 90.5.40.71(1) must comply with the required minimum building setbacks or be authorized by a Section 45 Planning Act minor variance.

(3) Permitted Setbacks for Lawfully Existing Building from a Lane

In the Open Space Zone category, if the lawful distance of a lawfully existing building or structure from the original centreline of a lane is less than the required minimum distance from the original centreline of the lane, that lawful distance is the minimum distance from the original centreline of the lane for that lawfully existing building or structure.

(4) Additions Above Lawfully Existing Buildings in Relation to a Lane

The required minimum distance from the original centreline of a lane for any addition or extension above a lawfully existing building or structure referred to in regulation 90.5.40.71(3) is the required minimum distance from the original centreline of the lane permitted by regulation $90.5 .40 .71(3)$. 


\subsubsection{Energy Regulations}

\subsubsection{General}

(1) Renewable Energy or Cogeneration Energy Device - Location Restriction In the Open Space Zone category, a device producing renewable energy or cogeneration energy may be no closer to a lot line than the greater of:

(A) 10 metres;

(B) the minimum building setback requirements; or

(C) a distance equal to the height of the device, measured between the average grade at its base to the elevation of the highest part of the device.

(2) Renewable Energy Device - Height Requirements

In the Open Space Zone category, a photovoltaic solar energy device or a thermal solar energy device that is:

(A) on a building:

(i) must comply with the required minimum building setbacks for a building on the lot; and

(ii) no part of the device may be higher than 3.0 metres above the permitted maximum height for the building; and

(B) ground mounted, no part of the device may be more than 5.0 metres above the average grade at the base of the device.

(3) Wind Energy Device - Setbacks

In the Open Space Zone category, no part of a wind energy device may be closer to a lot line than the greater of:

(A) the required minimum building setbacks for a building on the lot; or

(B) a distance equal to two times the height of the device, measured between the average grade at its base to the elevation of the highest part of the device. 
(4) Wind Energy Device - Height

In the Open Space Zone category, no part of a wind energy device may be more than 15.0 metres above the average grade at the base of the device.

(5) Geo-energy Requirements

In the Open Space Zone category, any above-ground part of a geo-energy device:

(A) must be set back at least 10.0 metres from any lot line; and

(B) must comply with the requirements for a building or structure, other than a required minimum building setback less than the requirement in (A) above.

(6) Cogeneration Device

In the Open Space Zone category, a cogeneration energy device must be inside a permitted building.

90.5.80 Parking

90.5.80.1 General

(1) Use of Required Parking Space

A parking space required by this By-law for a use in the Open Space Zone category must be available for the use for which it is required.

90.5.80.10 Location

(2) Location of Required Parking Spaces

A parking space must be on the same lot as the use for which the parking space is required. 


\section{APPENDIX C}

\section{ONTARIO REGULATION 166/06}

1. In this Regulation,

"Authority" means the Toronto and Region Conservation Authority. O. Reg. 166/06, s. 1.

\section{Development prohibited}

2. (1) Subject to section 3, no person shall undertake development or permit another person to undertake development in or on the areas within the jurisdiction of the Authority that are,

(a) adjacent or close to the shoreline of the Great Lakes-St. Lawrence River System or to inland lakes that may be affected by flooding, erosion or dynamic beaches, including the area from the furthest offshore extent of the Authority's boundary to the furthest landward extent of the aggregate of the following distances:

(i) the 100 Year flood level, plus an allowance for wave uprush and other water related hazards,

(ii) the predicted long-term stable slope projected from the existing stable toe of the slope or from the predicted location of the toe of the slope as that location may have shifted as a result of shoreline erosion over a 100-year period,

(iii) where a dynamic beach is associated with the waterfront lands, an allowance of 30 metres inland to accommodate dynamic beach movement, and

(iv) an allowance of 15 metres inland;

(b) river or stream valleys that have depressional features associated with a river or stream, whether or not they contain a watercourse, the limits of which are determined in accordance with the following rules:

(i) where the river or stream valley is apparent and has stable slopes, the valley extends from the stable top of bank, plus 15 metres, to a similar point on the opposite side,

(ii) where the river or stream valley is apparent and has unstable slopes, the valley extends from the predicted long term stable slope projected from the existing stable slope or, if the toe of the slope is unstable, from the predicted location of the toe of the slope as a result of stream erosion over a projected 100-year period, plus 15 metres, to a similar point on the opposite side,

(iii) where the river or stream valley is not apparent, the valley extends the greater of, 
(A) the distance from a point outside the edge of the maximum extent of the flood plain under the applicable flood event standard, plus 15 metres, to a similar point on the opposite side, and

(B) the distance from the predicted meander belt of a watercourse, expanded as required to convey the flood flows under the applicable flood event standard, plus 15 metres, to a similar point on the opposite side;

(c) hazardous lands;

(d) wetlands; or

(e) other areas where development could interfere with the hydrologic function of a wetland, including areas within 120 metres of all provincially significant wetlands and wetlands on the Oak Ridges Moraine, and within 30 metres of all other wetlands. O. Reg. 166/06, s. 2 (1); O. Reg. 82/13, s. $1(1,2)$.

(2) All areas within the jurisdiction of the Authority that are described in subsection (1) are delineated as the "Regulation Limit" shown on a series of maps filed at the head office of the Authority under the map title "Ontario Regulation 97/04: Regulation for Development, Interference with Wetlands and Alterations to Shorelines and Watercourses". 0. Reg. $82 / 13$, s. 1 (3).

(3) If there is a conflict between the description of areas in subsection (1) and the areas as shown on the series of maps referred to in subsection (2), the description of areas in subsection (1) prevails. O. Reg. 82/13, s. 1 (3).

\section{Permission to develop}

3. (1) The Authority may grant permission for development in or on the areas described in subsection 2 (1) if, in its opinion, the control of flooding, erosion, dynamic beaches, pollution or the conservation of land will not be affected by the development. 0. Reg. 166/06, s. 3 (1).

(2) The permission of the Authority shall be given in writing, with or without conditions. O. Reg. 166/06, s. 3 (2).

(3) Subject to subsection (4), the Authority's executive committee, or one or more employees of the Authority that have been designated by the Authority for the purposes of this section, may exercise the powers and duties of the Authority under subsections (1) and (2) with respect to the granting of permissions for development in or on the areas described in subsection 2 (1). 0. Reg. 82/13, s. 2.

(4) A designate under subsection (3) shall not grant a permission for development with a maximum period of validity of more than 24 months. O. Reg. 82/13, s. 2. 


\section{TRCA Living Cities Policy}

\subsection{Conservation Authorities Act}

The Conservation Authorities Act provides the legal basis for TRCA's mandate to undertake watershed planning and management programs that prevent, eliminate, or reduce the risk to life and property from flood hazards and erosion hazards, as well as encourage the conservation and restoration of natural resources.

\subsubsection{Objects of a Conservation Authority}

Section 20 of the Conservation Authorities Act sets out the objects of a conservation authority (CA):

20. The objects of an authority are to establish and undertake, in the area over which it has jurisdiction, a program designed to further the conservation, restoration, development and management of natural resources other than gas, oil, coal and minerals. R.S.O. 1990, c. C.27, s. 20.

\subsubsection{Powers of a Conservation Authority}

For the purposes of accomplishing these objects, section 21 of the Conservation Authorities Act assigns numerous powers to a conservation authority (CA) as follows:

(a) to study and investigate the watershed and to determine a program whereby the natural resources of the watershed may be conserved, restored, developed and managed; and restoration of natural resources.

(b) for any purpose necessary to any project under consideration or undertaken by the authority, to enter into and upon any land and survey and take levels of it and make such borings or sink such trial pits as the authority considers necessary;

(c) to acquire by purchase, lease or otherwise and to expropriate any land that it may require, and, subject to subsection (2), to sell, lease or otherwise dispose of land so acquired;

(d) despite subsection (2), to lease for a term of five years or less land acquired by the authority;

(e) to purchase or acquire any personal property that it may require and sell or otherwise deal therewith; 
(f) to enter into agreements for the purchase of materials, employment of labour and other purposes as may be necessary for the due carrying out of any project;

(g) to enter into agreements with owners of private lands to facilitate the due carrying out of any project;

(h) to determine the proportion of the total benefit afforded to all the participating municipalities that is afforded to each of them;

(i) to erect works and structures and create reservoirs by the construction of dams or otherwise;

(j) to control the flow of surface waters in order to prevent floods or pollution or to reduce the adverse effects thereof;

(k) to alter the course of any river, canal, brook, stream or watercourse, and divert or alter, as well temporarily as permanently, the course of any river, stream, road, street or way, or raise or sink its level in order to carry it over or under, on the level of or by the side of any work built or to be built by the authority, and to divert or alter the position of any water-pipe, gas-pipe, sewer, drain or any telegraph, telephone or electric wire or pole;

(l) to use lands that are owned or controlled by the authority for purposes, not inconsistent with its objects, as it considers proper;

(m) to use lands owned or controlled by the authority for park or other recreational purposes, and to erect, or permit to be erected, buildings, booths and facilities for such purposes and to make charges for admission thereto and the use thereof;

(m.1) to charge fees for services approved by the Minister;

(n) to collaborate and enter into agreements with ministries and agencies of government, municipal councils and local boards and other organizations;

(o) to plant and produce trees on Crown lands with 
the consent of the Minister, and on other lands with the consent of the owner, for any purpose;

(p) to cause research to be done;

(q) generally to do all such acts as are necessary for the due carrying out of any project. R.S.O. 1990, c. C.27, s. 21; 1996, c. 1, Sched. M, s. 44 (1, 2); 1998, c. 18, Sched. I, s. 11.

Section 20 of the Conservation Authorities Act provides the mandate for a CA to offer a broad resource management program, while section 21 provides the mandate to have watershed-based resource management programs and/ or policies that are approved by the Board of Directors.

All of TRCA's watershed research programs inform policy development and application in the planning and development process.

\subsubsection{Regulations of a Conservation Authority}

Under the provisions of section 28 of the Conservation Authorities Act, TRCA administers a Development, Interference with Wetlands and Alterations to Shorelines and Watercourses regulation (http://www.trca.on.ca/ dotAsset/15293.pdf). Through this regulation, TRCA has the ability to:

(a) prohibit, regulate or require the permission

of the authority for straightening, changing, diverting or interfering in any way with the existing channel of a river, creek, stream or watercourse, or for changing or interfering in any way with a wetland;

(b) prohibit, regulate or require the permission of the authority for development, if in the opinion of the authority, the control of flooding, erosion, dynamic beaches or pollution or the conservation of land may be affected by the development. The policies for the implementation of TRCA's regulation are contained in Section 8.0 of The Living City Policies.

8.0 Policies for the Administration of TRCA's Development, Interference with Wetlands and Alterations to Shorelines and Watercourses Regulation

The following policies are used to administer TRCA's "Development, Interference with Wetlands and Alterations to Shorelines and Watercourses Regulation" pursuant to Section 28 of the Conservation Authorities Act. These policies must be considered in their entirety, since activities under the Regulation may influence valley and stream corridors, wetlands, shorelines, watercourses and hazardous lands, either singularly or in combination. 
The policies in this Section incorporate the valuable foundation of principles and policy intent established by TRCA's Valley and Stream Corridor Management Program (1994). Additionally, the principles and management approach to flooding and erosion hazards in TRCA's Lake Ontario waterfront programs have also been included.

Applicants are encouraged to refer to TRCA's Planning and Development Procedural Manual which describes the Regulation permitting process in more detail. The Manual is intended to offer guidance on the permit review and approval process and includes technical guidelines and checklists to assist applicants with their submissions. Applicants are required to consult with TRCA staff to confirm complete application requirements prior to submission.

In addition to TRCA's regulatory responsibilities under the Conservation Authorities Act, TRCA has a significant advisory role under the Planning Act to member municipalities as described in Sections 3 and 7, including the delegated responsibility to represent the "Provincial Interest" on natural hazards. In participating in the review of applications under the Planning Act, TRCA will ensure the applicant and municipal planning authority are aware of the Section 28 Regulation and requirements under the Conservation Authorities Act, where applicable, and assist in the coordination of these applications to avoid ambiguity, conflict and unnecessary delay or duplication in the process. Although permission under Section 28 may not be issued for many years after a planning application, in order to support the planning application, TRCA needs to ensure that the requirements under the Regulation process can likely be fulfilled at the time a permit application is received. Similarly, this applies to applications reviewed under other legislation such as the Niagara Escarpment Planning and Development Act and the Environmental Assessment Act. Where comments or conditions provided by TRCA on these applications have not been duly addressed or applied by the approval authority, such planning decisions do not bind TRCA's permitting process.

Alternatively, it is also recognized that there maybe historic planning approval decisions that were made in the absence of current technical information related to natural hazards or natural features such as wetlands, which would now preclude development. The Conservation Authorities Act is the jurisdictional authority in the permitting process and does not provide for the "grandfathering" of historical planning decisions. Where it is technically feasible and appropriate, innovative design approaches may be considered to address site constraints and accommodate the development while still meeting current regulatory requirements. 


\section{References}

Allen, G. (2011, 05 30). Finding New Uses For Troubled Golf Courses. Retrieved from NPR: https://www.npr.org/2011/05/30/136788050/finding-new-uses-for-troubled-golf-coursesin-florida

Ann-Moore, W. (2018, 05 14). Downtown St. Petersburg church agrees to sell its parking lot for $\$ 5.6$ million. Retrieved from Tampa Bay Times: https://www.tampabay.com/news/business/economicdevelopment/Downtown-StPetersburg-church-agrees-to-sell-its-parking-lot-for-5-6-million-_168084779

Artuso, A. (2018, 01 07). City-run golf courses in the hole: Report. Retrieved from Toronto Sun: https://torontosun.com/news/local-news/city-run-golf-courses-in-the-hole-report

Attfield, P. (2017, 05 26). Growing cities struggle to stay green. Retrieved from Globe and Mail: https://www.theglobeandmail.com/life/growing-cities-struggle-to-staygreen/article35107379/

Breen, K. (2018, 11 09). Toronto to open 3 new shelters to tackle winter demand. Retrieved from Global News : https://globalnews.ca/news/4647883/toronto-shelters-winter-demands/

Cain, P. (2016, 04 10). Golfers are disappearing from public city courses. Should some be made into parks? Retrieved from Global News : https://globalnews.ca/news/2612990/as-fewergolfers-use-public-courses-should-some-be-made-into-parks/

Camrost Felcorp \& Diamondcorp. (n.d.). Project. Retrieved from The Foxbar Collection at Blue Diamond: http://thefoxbar.ca/project/

Canadian Stage . (2017, 07 13). It's happening! Let's kick off the 35th season of Shakespeare in High Park. Tweet . Toront, Ontario, Canada: Twitter .

Chiusano, A. (2018, 10 05). The 25 biggest college football stadiums in the country. Retrieved from NCAA.com: https://www.ncaa.com/news/football/article/2018-07-30/25-biggestcollege-football-stadiums-country

City of Calgary. (2018). Cross-country skiing and snowshoeing. Retrieved from City of Calgary : http://www.calgary.ca/CSPS/Parks/Pages/Locations/Cross-country-skiing.aspx

City of Edmonton. (2019). Riverside Golf Course Cross-Country Ski Trails. Retrieved from City of Edmonton: https://www.edmonton.ca/activities_parks_recreation/skiing-riverside-golfcourse.aspx 
City of Mississauga $\cdot$ (2015, 07 04). Soccer + Golf $=$ FootGolf . Retrieved from City of Mississauga :

http://www.mississauga.ca/portal/cityhall/pressreleases?paf_gear_id=9700020\&returnUrl $=/$ portal $/$ cityhall $/$ pressreleases\&itemId $=4900458 \mathrm{q}$

City of Mississauga. (n.d.). FootGolf. Retrieved from BreaBen Golf Course: http://www.mississauga.ca/portal/discover/footgolf

City of Toronto . (2017). Future Options for City Operated Golf Courses. Toronto: City of Toronto.

City of Toronto . (n.d.). Dentonia Park. Retrieved from City of Toronto : https://www.toronto.ca/explore-enjoy/recreation/golf/dentonia-park/

City of Toronto. (n.d. ). Neighbourhood Improvement Area Profiles. Retrieved from City of Toronto : https://www.toronto.ca/city-government/data-research-maps/neighbourhoodscommunities/nia-profiles/

City of Toronto. (n.d.). Golf. Retrieved from City of Toronto : https://www.toronto.ca/exploreenjoy/recreation/golf/

City of Toronto. (n.d.). Scarlett Woods. Retrieved from City of Toronto : https://www.toronto.ca/explore-enjoy/recreation/golf/scarlett-woods/

City of Toronto Social Development, Finance \& Administration . (2019). Toronto Strong Neighbourhoods Strategy 2020 Neighbourhood Action Plans . Toronto: City of Toronto .

City of Toronto Social Policy, Analysis \& Research. (2018, 02). Oakridge. Retrieved from Toronto Neighbourhood Profile: https://www.toronto.ca/ext/sdfa/Neighbourhood\%20Profiles/pdf/2016/pdf1/cpa121.pdf

City of Toronto Social Policy, Analysis \& Research. (2018, 02). Rockcliffe-Smythe. Retrieved from 2016 Neighbourhood Profile: https://www.toronto.ca/ext/sdfa/Neighbourhood\%20Profiles/pdf/2016/pdf1/cpa111.pdf

City of Toronto Treasurer and City Solicitor. (2012). Golf Courses - Assessment Review Board Appeals. Toronto : City of Toronto.

Craine, J.-A. (2017, 12 07). Ladies ' Golf Club sells acreage for $\$ 23$ mil. Retrieved from Post City Toronto: https://www.postcity.com/Eat-Shop-Do/Do/November-2017/Ladies-GolfClub-sells-acreage-for-23-mil/

Crownover, M. (n.d.). How Many Acres Are Needed for an 18 Hole Golf Course? Retrieved from Golfweek : https://golftips.golfweek.com/many-acres-needed-18-hole-golf-course1812.html 
Deegan, J. S. (2015, 05 20). Gone Loonie? Splurge on the most expensive golf courses in Canada. Retrieved from Golf Advisor : https://www.golfadvisor.com/articles/goneloonie-splurge-on-the-most-expensive-golf-courses-in-canada

Dickson, C. (2018, 01 16). 'Small tent city' proposed for former golf course. Retrieved from CBC.ca: https://www.cbc.ca/news/canada/british-columbia/kamloops-tent-city-proposal1.4489922

Dixon, G. (2018, 01 29). Neighbourhood churches find a new mission. Retrieved from Globe and Mail : https://www.theglobeandmail.com/report-on-business/industry-news/propertyreport/property-report-churches/article37746572/

Draaisma, M. (2018, 10 08). Keesmaat proposes converting 3 city golf courses into public spaces. Retrieved from CBC.ca: https://www.cbc.ca/news/canada/toronto/jenniferkeesmaat-golf-courses-public-spaces-proposal-1.4854524

Festivals Toronto. (n.d.). Shakespeare in High Park. Retrieved from Festivals Toronto: https://festivalstoronto.com/arts-theatre/shakespeare-in-high-park/

Gattis, P. (2017, 06 23). Huntsville's municipal golf course to be converted into multi-use park. Retrieved from AL.com: https://www.al.com/news/huntsville/index.ssf/2017/06/huntsvilles_muni_golf_course_t.h tml

Gee, M. (2017, 12 22). Born again ... as condominiums. Retrieved from Globe and Mail: https://www.theglobeandmail.com/news/toronto/abandoned-toronto-churches-beingreborn-ascondominiums/article37423283/

Giegerich, A. (2014, 05 20). City bets $\$ 5$ million on Colwood Golf Course, Cully land purchases . Retrieved from Portlanf Business Journal : https://www.bizjournals.com/portland/morning_call/2014/03/city-bets-5-million-oncolwood-golf-course-cully.html

Goffin, P. (2018, 01 09). Toronto considers review of city golf courses after years of financial loss. Retrieved from Global: ourses.ryerson.ca/d21/login?target $=\% 2 \mathrm{fd} 21 \% 2 \mathrm{flms} \% 2$ fgrades $\% 2 \mathrm{fmy} \_g r a d e s \% 2 \mathrm{fmain} . \mathrm{d} 21$ $\% 3$ fou $\% 3 d 198798 \&$ sessionExpired $=0$

Golf Advisor. (2019). About Toronto. Retrieved from Golf Advisor : https://www.golfadvisor.com/destinations/167-toronto-on/

Golf Canada. (2015, 07 13). Where Canada's golf business stands. Retrieved from Golf Canada: http://golfcanada.ca/article/where-canadas-golf-business-stands

Golf Canada. (2017). Annual Report 2017. Oakville: Golf Canada. 
Golf Canada. (2019). The History of the Game. Retrieved from Golf Canada:

http://golfcanada.ca/history-of-the-game/

Google Earth. (n.d.). Google.

Grange, M., \& Willis, A. (2018, 04 18). Teeing up for snob appeal. Retrieved from Globe and Mai: https://www.theglobeandmail.com/globe-investor/investment-ideas/teeing-up-forsnob-appeal/article772172/

Green, J. (2013, 04 15). Open season for Toronto's golf courses. Retrieved from Toronto Star: https://www.thestar.com/news/gta/2013/04/15/open_season_for_torontos_golf_courses.ht $\mathrm{ml}$

Grooms, T. (2010). Alternatives to Golf Course Developments in an Environmentally Sensitive Market. Cornell Real Estate Review, 88-99.

High Park Toronto. (n.d.). Home Page. Retrieved from High Park Toronto: http://www.highparktoronto.com/

Howes, N. (2017, 04 21). Oakville's Glen Abbey golf course property rich in history. Retrieved from Inside Halton : https://www.insidehalton.com/news-story/7255368-oakville-s-glenabbey-golf-course-property-rich-in-history/

Judge, S. (2015, 08 31). Selling Municipal Golf Course: The rest of the story. Retrieved from The Chronical Journal : http://www.chroniclejournal.com/opinion/columns/sellingmunicipal-golf-course-the-rest-of-the-story/article_59235126-4dc3-11e5-849123698636a5fd.html

Lea, D. (2018, 12 12). Town of Oakville dealt another courtroom setback in fight to save Glen Abbey Golf Course. Retrieved from Inside Halton: https://www.insidehalton.com/newsstory/9080143-town-of-oakville-dealt-another-courtroom-setback-in-fight-to-save-glenabbey-golf-course/

Lorinc, J. (2016, 04 07). Is this the end of Ontario's suburban golf courses? Retrieved from TVO.org: https://www.tvo.org/article/current-affairs/is-this-the-end-of-ontariossuburban-golf-courses

McQuesten Urban Farm. (n.d.). Our Story. Retrieved from McQuesten Urban Farm: https://www.mcquestenurbanfarm.ca/our-story

Murthy, R. (2017, 11 05). Overcrowded \& underfunded: no relieffor TTC bus riders in 2018. Retrieved from City News : https://toronto.citynews.ca/2017/11/15/overcrowdedunderfunded-no-relief-ttc-bus-riders-2018/ 
Noor, J. (2016, 03 27). GTA housing developers targeting golf courses. Retrieved from Toronto Star: https://www.thestar.com/news/gta/2016/03/27/gta-housing-developers-targetinggolf-courses.html

Pagliaro, J. (2017, 04 25). Planned closure of hundreds of social housing units called 'failure' of governments as waiting list grows. Retrieved from Toronto Star: https://www.thestar.com/news/city_hall/2017/04/25/planned-closure-of-hundreds-ofsocial-housing-units-called-failure-of-governments-as-waiting-list-grows.html

Parkkari, J., Natri, A., Kannus , P., Manttari, A., Laukkanen , R., Happasalo, H., . . Vuori , I. (2000). A controlled trial of the health benefits of regular walking on a golf course. American Journal of Medicine, 102-108.

Pelley, L. (2015, 04 12). Toronto striving for green spaces in a growing city. Retrieved from Toronto Star: https://www.thestar.com/news/gta/2015/04/12/toronto-striving-for-greenspaces-in-a-growing-city.html

Piedmont Park Conservancy. (n.d.). Park History. Retrieved from Piedmont Park Conservancy: https://www.piedmontpark.org/park-history/

Poulsen, M. N., Neff, R. A., \& Winch, P. J. (2017). The multifunctionality of urban farming: perceived benefits for neighbourhood improvement. Local Environment, 1411-1427.

Roberts, E. (2017, 08 17). Cemetery plans take shape for defunct golf course. Retrieved from South Florida Sun Sentinel : https://www.sun-sentinel.com/local/broward/deerfieldbeach/fl-dff-fairway-0809-20170807-story.html

Score Golf. (2018, 07). Top 100 Golf Courses in Canada 2018. Retrieved from Score Golf : http://scoregolf.com/top-100-2018/

Smith, J. (2016, 02 26). Mayor wants city to sell another golf course to raise revenues, cut expenses. Retrieved from tbnewswatch.com : https://www.tbnewswatch.com/localnews/mayor-wants-city-to-sell-another-golf-course-to-raise-revenues-cut-expenses404688

Sorensen, C. (2014, 07 04). Why Canadian golf is dying. Retrieved from Maclean's: https://www.macleans.ca/economy/business/the-end-of-golf/

Statistics Canada. (2017, 04 23). Focus on Geography Series, 2016 Census. Retrieved from Statistics Canada: https://www12.statcan.gc.ca/census-recensement/2016/as-sa/fogsspg/Facts-cma-eng.cfm?LANG=Eng\&GK=CMA\&GC=535\&TOPIC $=1$

Stinson, S. (2017, 07 17). As courses close and millennials turn their backs, golf reckons with uncertain future. Retrieved from National Post: https://nationalpost.com/sports/golf/ascourses-close-and-millennials-turn-their-backs-golf-reckons-with-uncertain-future 
The Toronto Golf Club . (n.d.). Toronto Golf Club's History. Retrieved from The Toronto Golf Club : https://www.torontogolfclub.com/Membership/History2-(1)

The Trust for Public Land . (2016, 07 08). For park planners, creative compromise is par for the course. Retrieved from The Trust for Public Land : https://www.tpl.org/blog/colwoodpark\#sm.0000w6w8u466pd97qu42ftmj5kvbu

The Trust for Public Land . (2017, 11 15). The Trust for Public Land will buy San Geronimo Golf Course in Marin. Retrieved from The Trust for Public Land : https://www.tpl.org/media-room/trust-public-land-will-buy-san-geronimo-golf-coursemarin\#sm.0000w6w8u466pd97qu42ftmj5kvbu

Toronto Real Estate Board . (2018, 10 18). Rental Market Report. Retrieved from Toronto Real Estate Board: http://trebhome.com/market_news/rental_reports/pdf/rental_report_Q32018.pdf

Toronto Real Estate Board . (2019, 01 04). Toronto Real Estate Board MLS Home Price Index December 2018. Retrieved from Toronto Real Estate Board : http://trebhome.com/market_news/home_price_index/pdf/TREB_MLS_HPI_Public_Tabl es_1218.pdf

Toronto Transit Commission . (2018). TTC Corporate Plan 2018-2022. Toronto : Toronto Transti Commission.

TRCA. (2004). Ontario Regulation 166/06. Toronto .

TRCA. (2018). Flood Plain Map . Retrieved from Toronto and Region Conservation Authority: https://trca.ca/conservation/flood-risk-management/flood-plain-map-viewer/\#map

TRCA. (2019). Regulated Area Search . Retrieved from TRCA: https://trca.ca/planningpermits/regulated-area-search-v2/

University of Michigan . (2017, 11 05). UM Golf Course shuts down some parking areas ahead of Michigan game. Retrieved from MLIve.com: https://www.mlive.com/news/annarbor/index.ssf/2017/11/um_golf_course_shuts_down_two.html

University of Michigan. (2019). Parking Information for Football Game Days. Retrieved from GoBlue.com:

https://mgoblue.com/news/2009/8/26/Parking_Information_for_Football_Game_Days.as px 
